\title{
Antimicrobial Resistance: Its Surveillance, Impact, and Alternative Management Strategies in Dairy Animals
}

\author{
Chetan Sharma ${ }^{1}$, Namita Rokana ${ }^{1}$, Mudit Chandra $^{2}$, Brij Pal Singh ${ }^{1}$, \\ Rohini Devidas Gulhane', Jatinder Paul Singh Gill ${ }^{3}$, Pallab Ray ${ }^{4}$, Anil Kumar Puniya ${ }^{1}$ \\ and Harsh Panwar ${ }^{*}$
}

${ }^{1}$ Department of Dairy Microbiology, College of Dairy Science and Technology, Guru Angad Dev Veterinary and Animal Sciences University (GADVASU), Ludhiana, India, ${ }^{2}$ Department of Veterinary Microbiology, College of Veterinary Science, Guru Angad Dev Veterinary and Animal Sciences University (GADVASU), Ludhiana, India, ${ }^{3}$ School of Public Health and Zoonoses, Guru Angad Dev Veterinary and Animal Sciences University (GADVASU), Ludhiana, India, ${ }^{4}$ Department of Medical Microbiology, Post Graduate Institute for Medical Education and Research (PGIMER), Chandigarh, India

OPEN ACCESS

Edited by:

Massimo Amadori,

Istituto Zooprofilattico

Sperimentale della Lombardia e dell'Emilia Romagna Bruno

Ubertini (IZSLER), Italy

Reviewed by:

Rafael Antonio Casarin

Penha Filho,

Universidade Estadual

Paulista Júlio de Mesquita

Filho (UNESP), Brazil

Kuldeep Dhama,

Indian Veterinary Research

Institute (IVRI), India

*Correspondence:

Harsh Panwar

drhpanwar@gmail.com

Specialty section:

This article was submitted to Veterinary Infectious Diseases,

a section of the journal

Frontiers in Veterinary Science

Received: 12 September 2017

Accepted: 15 December 2017

Published: 08 January 2018

Citation:

Sharma C, Rokana N, Chandra M, Singh BP, Gulhane RD, Gill JPS, Ray P, Puniya AK and Panwar $H$ (2018) Antimicrobial Resistance:

Its Surveillance, Impact, and Alternative Management

Strategies in Dairy Animals.

Front. Vet. Sci. 4:237.

doi: 10.3389/fvets.2017.00237
Antimicrobial resistance (AMR), one among the most common priority areas identified by both national and international agencies, is mushrooming as a silent pandemic. The advancement in public health care through introduction of antibiotics against infectious agents is now being threatened by global development of multidrug-resistant strains. These strains are product of both continuous evolution and un-checked antimicrobial usage (AMU). Though antibiotic application in livestock has largely contributed toward health and productivity, it has also played significant role in evolution of resistant strains. Although, a significant emphasis has been given to AMR in humans, trends in animals, on other hand, are not much emphasized. Dairy farming involves surplus use of antibiotics as prophylactic and growth promoting agents. This non-therapeutic application of antibiotics, their dosage, and withdrawal period needs to be re-evaluated and rationally defined. A dairy animal also poses a serious risk of transmission of resistant strains to humans and environment. Outlining the scope of the problem is necessary for formulating and monitoring an active response to AMR. Effective and commendably connected surveillance programs at multidisciplinary level can contribute to better understand and minimize the emergence of resistance. Besides, it requires a renewed emphasis on investments into research for finding alternate, safe, cost effective, and innovative strategies, parallel to discovery of new antibiotics. Nevertheless, numerous direct or indirect novel approaches based on host-microbial interaction and molecular mechanisms of pathogens are also being developed and corroborated by researchers to combat the threat of resistance. This review places a concerted effort to club the current outline of AMU and AMR in dairy animals; ongoing global surveillance and monitoring programs; its impact at animal human interface; and strategies for combating resistance with an extensive overview on possible alternates to current day antibiotics that could be implemented in livestock sector.

Keywords: antimicrobial resistance, antimicrobial usage, multidrug resistance, dairy farming, surveillance, alternative treatment strategies 


\section{INTRODUCTION}

Microorganisms are among the man's best friends and also worst enemies. Knowledge about them has grown at fast pace; since their discovery by Leeuwenhoek and other eminent scientists, recognizing them as agents of infection. It took time to establish their role in food and fermentation and later their positive impact over human health (1). Exploitation of microbes and their metabolites for their useful applications in food, feed, dairy, fermentation, pharmaceutical, and other areas is practiced since centuries now (2-4). However, besides having beneficial roles, their impact as a threatening agent against humans, animals, and vegetation persists in form of many infections in human and animals and food spoilage, adding considerable load on individual and global economy. To counter these living threat agents, several measures, especially administration of antimicrobials, are employed globally. Discovery of first antibiotic, penicillin, retarded the prevalence of infectious diseases and saved millions of life particularly during Second World War. However, Sir Alexander Fleming, during his Nobel Prize speech in 1945, stated that bacteria could develop resistance against antibacterial therapies, and it was not much later when cases of non-efficacy of the wonder drug itself were reported $(5,6)$. This started the reporting of failure of other therapeutic drugs against infectious agents, later recognized as drug resistance, antimicrobial resistance (AMR), or antibiotic resistance; challenging the efficacy of modern therapeutic regimes. AMR in microbes is defined as their unresponsiveness to standard doses of clinically relevant antimicrobial drugs (7). Broadly, it is the property of microbes that overpower the antagonistic effects of antibiotics, to which they were earlier sensitive, resulting in their survival despite exposure to standard doses of antibiotic. This natural phenomenon further gets accelerated by the selective pressure generated by the use; more correctly, misuse of antibiotics. AMR has emerged as a threat to the current effective treatment for an ever-increasing range of microbial infections. It results in reduced efficacy of antibiotics; making treatment complicated, time consuming, costly, or sometimes even impossible. The discorvery of each and every new antibiotic has been followed by reports of emerging resistance against it (6).

Further, AMR do not respect geographical boundaries and can traverse among humans, animals across countries, mediated through resistant strains; without any specific information and check (8). In the era of globalization and urbanization, prescribed treatment fails to put a check over resistant strains; infectious diseases become uncontrollable; major surgeries are jeopardized; and ultimately resistant forms are left free to spread (9). Different countries and research bodies are reacting toward issue of AMR and millions of dollars are being spent over surveillance and research for the abatement of AMR in human pathogens. AMR in humans has been inter-connected with AMR in other populations and ecosystems. The problem of AMR is equally important and prevalent in animals; although emphasized to a lower extent. Antimicrobial agents are being employed for food animal production either as therapeutic, metaphylactic, prophylactic, or as growth promoter (10). As an outcome of extensive public health concern regarding antimicrobial growth promoter (AGP) usage in livestock, the European Union (EU) progressively banned all AGPs in the livestock industry (11). The emergence and spread of drug-resistant bacteria arise from a myriad of ecological and evolutionary interacting factors, either natural or human-driven. Widespread dependence over antimicrobial usage (AMU) in animals results in a selective pressure under which bacteria can either develop resistance-mediating mutations or acquire resistance genes. Indeed, the usage of antimicrobial agents is perhaps the major driving force in resistance development and dissemination (12). Possible factors associated with AMR in animal microflora have been depicted in Figure 1. The rapid emergence of resistance toward current day antibiotics generates a potential scope for modern and novel antibiotics for futuristic approaches (13). AMR is affecting diverse populations globally and requires a cheap and effective treatment/prevention strategy for public well-being (14). Hence, there is an urgent need to survey and study the prevalence of AMR in commensal and pathogenic flora of animals, especially of economic value, i.e., milking herds, to understand the possible mechanism of AMR and development of natural treatment strategies with novel target sites, which can prove to be alternative strategies for combating AMR. So, sufficiently detailed knowledge about multidrug-resistant (MDR) bacteria (quantitative understanding of the dynamics), and multiple resistance determinants in variable host (humans and animals) and different environmental compartments, is required to make useful predictions and designing regulatory measures at national as well as international levels. In light of emerging aspect of drug resistance, the present review underlines the responsible factors for developing burden of AMR crisis in dairy cattle. The role of concerned regulating authorities and practitioners for implementation of policies for antibiotic stewardship to seize the rising threats is also featured. Furthermore, we also record the plausible alternative therapeutic strategies currently being used or studied to limit AMR problem.

\section{AMU AND RESISTANCE IN DAIRY ANIMALS}

Milk, being the most popular natural health food, is consumed globally by members of every age group. This forms the basis of establishment of dairy farming and industry. Besides milk, dairy animals are also reared for meat purpose. Dairy animals maintained in large groups and conventional dairy farms are more frequently exposed to antimicrobials in comparison to those maintained as small holdings and practicing organic farming. The demand for animal source food is also increasing at a rapid rate (15). With this increasing demand, the value of veterinary drugs in international market augmented from 8.65 billion dollar in 1992 to 20 billion dollar in 2010 and is projected to touch 42.9 billion dollar mark by 2018 (16). Globally, animal farming relies heavily on the surplus use of antimicrobials for the improvement of animal health and greater productivity. According to Food and Drug Administration (FDA) (17), AMU in food animals in USA was estimated to account for $80 \%$ of the total nation's annual antimicrobial consumption. In 2012, 26 EU countries' average 


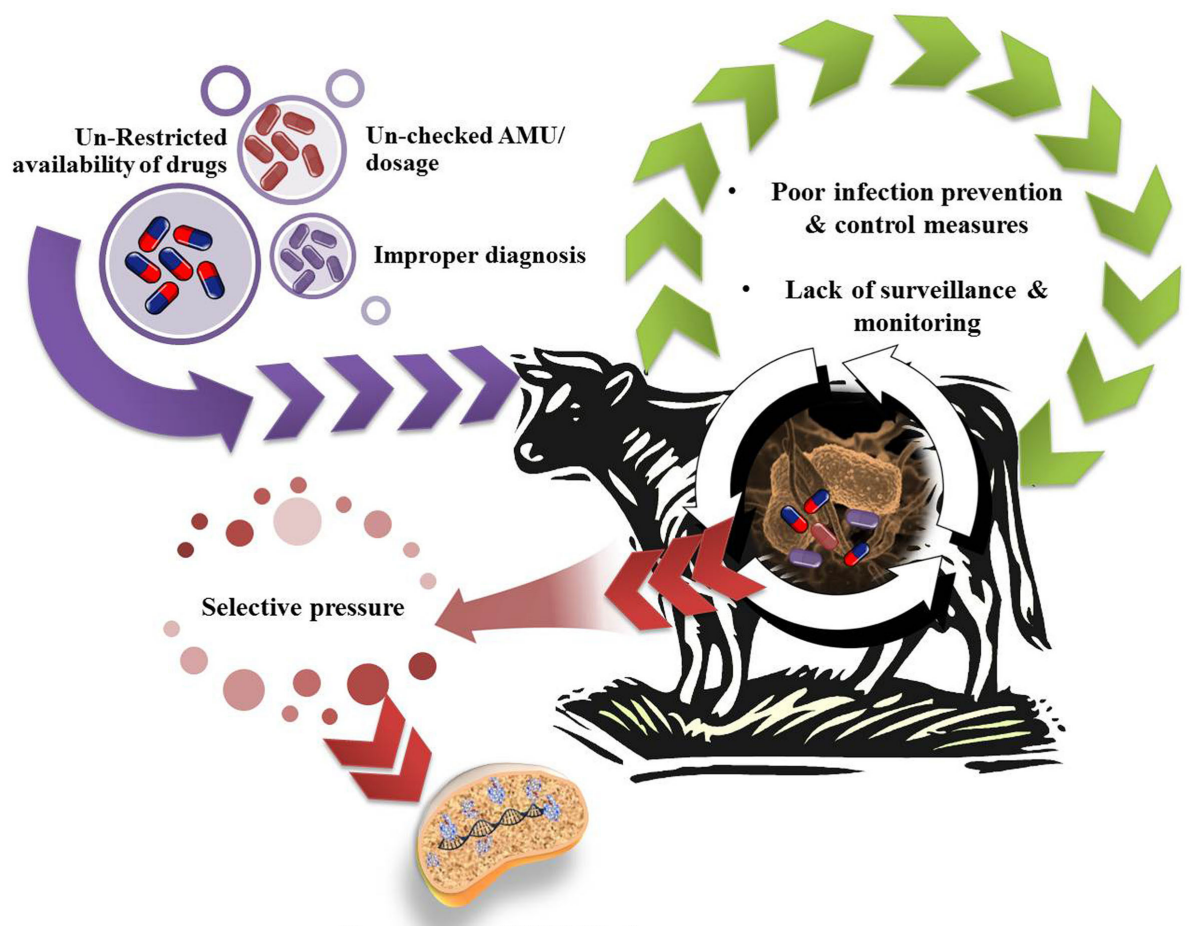

Emergence of AMR Strains

FIGURE 1 | Possible factors leading to antimicrobial resistance (AMR) in dairy animals.

consumption of antimicrobials was 116.4 and $144.0 \mathrm{mg} / \mathrm{kg}$ of estimated biomass in humans and animals, respectively (18). Increasing population will further generate a demand for highquality livestock products. In order to match this global demand for animal proteins, AMU in food animal production will rise over $67 \%$ by 2030 (19). The episodes of widespread resistance may be more consequential for developing countries, including India, where the infectious disease burden is very high and, therefore, attracts higher antimicrobial application for limiting morbidity and mortality (7). Presence of antimicrobial residues in food animal products (chicken meat and milk) has been reported from different parts of India, indicating wide AMU in food animal production in India (20-23). Predicting actual values of AMU in dairy farms is challenged by several factors, viz., lack of maintenance of antibiotic treatment records and written plans for treating sick animals; low dependence on veterinarian's advice; and administration by the owner itself. Also, there is considerable variation in the management practices associated with antibiotic use, varying globally from farm to farm (24). Hence, details on AMU in dairy animals are more presumptive. According to a survey conducted by the World Organization for Animal Health (OIE) in 2012, only $27 \%$ of the OIE member countries adopted an official system for recording AMU in livestock (24).

Antimicrobial usage is the major driving force for developing AMR in animal husbandry. Both commensal and pathogenic bacteria are challenged with antibiotics and in response AMR develops. Drug resistance development has been attributed mainly to suboptimal concentrations of antibiotics in the patients and supplementing subtherapeutic doses of antibiotics to promote growth in food animals (25). It has been observed that bacteria develop resistance through any of the four mechanisms, viz., antibiotic inactivation or its modification; alteration in the antibiotic target site; modification in the metabolic pathways to overcome antibiotic effect; and by minimizing entry and/ or promoting active efflux of the antibiotic (25). Microbes can build up resistance to antibiotics through mutating existing genes (vertical) (26), or through acquiring new genes from environment, other species, or strains (horizontal gene transfer) (27). The sharing of genetic information between bacteria occurs mainly through mobile genetic elements that includes phages, plasmids, and transposons (28). It has been observed that the resistance among bacterial species is via antibiotic-resistant genes and among the major genes leading to AMR includes blaTEM genes for the antibiotics penicillin/amoxicillin/ampicillin (29); van for glycopeptides (avoparcin/vancomycin) (30); erm gene cluster for macrolides (erythromycin/tylosin/tilmicosin/kitasamycin/ oleandomycin) (31); vatD, vatE, erm gene cluster, satA for streptogramins (virginiamycin/quinupristin-dalfopristin) (31); sul genes for sulfonamides (sulfisoxazole/sulfadimethoxine/sulfamethazine) (32); tet genes for tetracyclines (chlortetracycline/ oxytetracycline/doxycycline) (31); $\operatorname{rgp} A-F, m b r A-D$ genes for polypeptides (bacitracin); and $c m a A, f l o R, f e x A, f e x B, c f r$, cat gene for amphenicols (chloramphenicol) (33).

Presence of resistant pathogenic strains in food matrix creates a direct risk to public health. Food-producing animals are the primary reservoir of zoonotic pathogens. Most frequently 
encountered resistant pathogenic strains in dairy farming are Staphylococcus aureus, Escherichia coli, Listeria monocytogenes, Salmonella spp., etc. S. aureus is one among the leading causes of food-borne illnesses. Milk and dairy products are often contaminated with enterotoxigenic strains of $S$. aureus. Therefore, a survey report on the occurrence of $S$. aureus in meat and dairy products indicated around $68.8 \%$ strains resistance to at least one antibiotic tested. Usually, S. aureus is present on the skin and mucosae of animals, as well as frequently associated with subclinical mastitis, which leads to its entry into milk chain (34). In addition, around $3.75 \%$ of these $S$. aureus strains displayed methicillin resistance (35). Sasidharan et al. (36) also found methicillin- and vancomycin-resistant $S$. aureus in dairy products. Jamali and coworkers (37) also tested 2,650 samples of dairy products; out of which $S$. aureus was detected in $12.4 \%$ samples in which $16.2 \%$ were positive for methicillin resistance.

Besides, L. monocytogenes is another resistant bacteria frequently found in dairy products. For instance, oxacillin- and penicillin-resistant L. monocytogenes has been reported in dairy products from Lebanon (38). Similarly, a surveillance study carried out in Iran reported MDR Listeria spp. in around $7 \%$ of traditional dairy products screened in this study (39). Furthermore, antimicrobial-resistant enteric bacteria, mainly E. coli, have also been isolated from feces of healthy lactating dairy cattle (40). Shiga toxin-producing MDR E. coli strains have also been isolated from cow stool samples in Calcutta, India (41). Similarly, a number of studies have described the occurrence of extended-spectrum $\beta$-lactamase producing
E. coli in food-producing animals. Although, most of these studies are from western countries, quite a number of reports are available from Asia $(42,43)$. Additionally, antimicrobialresistant Salmonella spp. has also reported in cattle, milk, and milk products. In a study from Ethiopia, around $10.7 \%$ of cattle were found positive for MDR Salmonella spp. (44).

\section{ANIMAL-HUMAN INTERFACE}

As observed in human medicine, AMU in veterinary practice, even at a rational dose, may select the genes encoding resistance. These strains now encoding resistance traits can easily transfer to humans, denoting a public health hazard. A reservoir of such strains in dairy animals implies a potential risk for their transfer to humans. Drug-resistant strains of animal origin can spread to humans either through food supply chain (i.e., Meat and Dairy products); direct animal contact; or through environmental routes (18). Several researchers have proposed a relationship between AMU and the occurrence of antimicrobial-resistant strains not only in animals but also in humans having close contact. Any direct or indirect interaction between humans and animals may lead to zoonotic transmission of antibiotic-resistant strains and genes from food animals to humans (Figure 2). Occupationally exposed personnels, viz., farmers, food handlers and veterinarians, are more prone to getting colonized or infected with resistant strains $(45,46)$. Consumers may be exposed to resistant strains and genes through consumption of contaminated food products, i.e., meat, milk, and milk products.

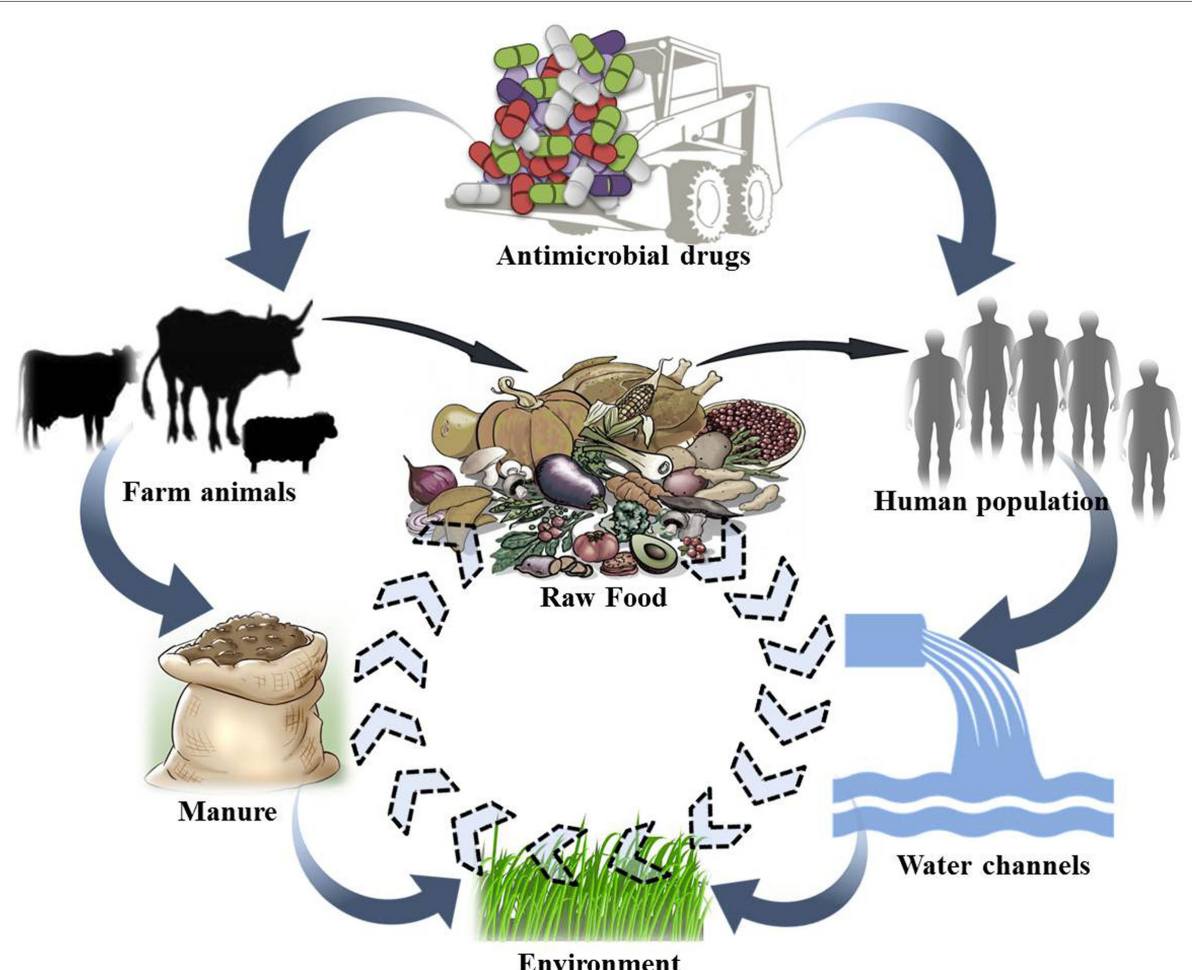

FIGURE 2 | Conceptual representation of possible movement of antibiotic-resistant bacterial strains/genes between different ecosystems. 
Recently, several reports have portrayed the presence of large number of resistant bacteria and corresponding genes in a variety of animal food products $(47,48)$. Whole-genome sequencing and phylogenetic studies proposed that the methicillin-resistant Staphylococcus aureus (MRSA) in livestock has evolved from methicillin-susceptible $S$. aureus strains of human origin. Quite a few studies have further identified similar or clonally related bacterial strains of animal origin in human populations without any direct exposure to animals, linking them to the consumption and/or handling of food (49). Recently, Horigana et al. (50) studied the risk assessment approach toward the transmission of ESBL-producing E. coli from food animals to humans via the food chain. Kock and his coworkers (51) also cited that livestock animals frequently transmit livestock-associated MRSA to exposed humans. Subsequent cases of infections in humans, resulting from resistant bacteria originating from animal source, are of paramount concern. The problem is more prominent in developing countries, where there are no established guidelines or guidelines that are not followed, and also have high burden of infectious disease along with comparatively low health-care spending $(37,52)$. MDR bacteria have been isolated from food animals throughout the developing world where AMU is unregulated (20).

\section{SURVEILLANCE AND MONITORING}

With the mounting pressure of AMR in veterinary system, several countries have initiated surveillance and monitoring programs. In 1997, the World Organization for Animal Health (OIE) proposed standards pertaining to resistance surveillance. The OIE Terrestrial Animal Health Code chapter 6.7 talks about the harmonization of surveillance and monitoring programs at national level; chapter 6.8 discusses about monitoring of the AMU patterns in food-producing animals; chapter 6.9 covers the judicious application of antimicrobials in veterinary practice; and chapter 6.10 includes the risk assessment for AMR arising from the AMU in animals $(53,54)$. These standards were accepted in 2003 along with the introduction of WHO Global Strategy for the containment of AMR. Collaborative consultations between WHO/OIE/FAO experts led to foundation of Codex Alimentarius Ad Hoc Inter governmental task force on AMR. This task force proposed the "Guidelines for Risk Analysis of Food-borne Antimicrobial Resistance," later on adopted by the Codex Alimentarius Commission in 2011 (55).

Surveillance program(s) aims at improved recording of emerging AMR, enhancing the active life of antimicrobial drugs, and providing guidance for the development and usage of newer drugs. Establishment of monitoring program requires consideration of different factors, such as selection of appropriate target bacterial strains to be included, sampling procedures, isolation and susceptibility testing methods, data recording, computing, and reporting. Monitoring and surveillance programs and methodologies followed differ between countries/ agencies and are influenced by varied agricultural practices, monitoring needs, and availability of guidelines. Surveillance programs implemented by different countries and agencies have been compiled in Table 1.
In order to monitor the status of AMR, the first model of national surveillance program was the Danish Integrated Antimicrobial Resistance Monitoring and Research Programme (DANMAP), initiated by the Danish Government in 1995. This program monitors the trend of AMU, status of resistance prevalence and changes over time, and analyzes the link, if any between the usage and resistance development among bacterial strains associated with animals and humans (58). As per the report of DANMAP, 2005 it was observed that from 1999 to 2005 the resistance in Salmonella Typhimurium isolated from pigs had increased resistant to tetracycline, sulfonamide, and ampicillin, and these increases were coincided with an increased consumption of tetracycline, sulfonamides, and broad-spectrum penicillin in pigs in the same period. Data from the human population too indicated almost the same pattern, and in the E. coli urine isolates resistance to ciprofloxacin, gentamicin, and cefuroxime increased significantly and was consistent with the parallel increases in the consumption of same or similar antimicrobials. These data from DANMAP, 2005 indicate the role of surveillance and monitoring for identification and policy formation at National level.

On similar pattern, National Antimicrobial Resistance Monitoring System (NARMS) was constituted in 1996 with joint efforts of the United States Department of Agriculture, FDA, and the Centers for Disease Control and Prevention (CDC). NARMS monitor changes in antimicrobial susceptibilities of zoonotic pathogens from diagnostic specimens (human and animal), healthy farm animals, and from raw product of food-producing animals at slaughter and processing (59). This program deals with studying the prevalence and trends of antimicrobial susceptibility among Salmonella spp. and other enteric organisms from the human and animal populations; proper identification of resistance strains; timely delivery of updated information to veterinarians and physicians for increasing the life span of approved antimicrobial drugs; and to properly identify the areas/voids for better research and investigation (60).

In 2009, European Medicines Agency (EMA) launched the European Surveillance of Veterinary Antimicrobial Consumption program to monitor AMU in animals from member states. EMA published a report on the sales of veterinary antimicrobial agents, categorized it and reported it in a harmonized manner (61). Apart from the Centre Européend' Etudes pour la Santé Animale (European Animal Health Centre) (CEESA), all the other European veterinary AMR surveillance and monitoring programs are functional at country level. For each of the CEESA programs, isolates are collected from up to nine countries across EU, using uniform collection methodology, followed by four resistance surveillance and monitoring programs, viz., VetPath, European Antimicrobial Susceptibility Surveillance in Animals (EASSA), ComPath, and MycoPath. VetPath examines the antimicrobial susceptibility pattern of major disease-causing bacterial pathogens; EASSA covers zoonotic and commensal bacteria; and MycoPath targets disease-causing mycoplasma species in food animals; while ComPath addresses major disease-causing bacterial pathogens in companion animals $(56,62)$.

The French Agency for Food Safety (Agence Francaise de Securite Sanitaire des Aliments, AFSSA) runs two independent 
TABLE 1 | Diverse antimicrobial resistance surveillance and monitoring programs $(49,56,57)$.

\begin{tabular}{|c|c|c|c|}
\hline Country & Regulatory body/Surveillance Program & Link & Testing protocol \\
\hline Denmark & $\begin{array}{l}\text { Danish Integrated Antimicrobial Resistance Monitoring } \\
\text { and Research Programme (DANMAP) }\end{array}$ & http://www.danmap.org & CLSI \\
\hline United States & $\begin{array}{l}\text { National Antimicrobial Resistance Monitoring System } \\
\text { (NARMS) }\end{array}$ & www.cdc.gov/narms/index.html & CLSI \\
\hline Netherlands & $\begin{array}{l}\text { Monitoring of Antimicrobial Resistance and Antibiotic } \\
\text { Usage in Animals in the Netherlands (MARAN) }\end{array}$ & $\begin{array}{l}\text { http://www.wageningenur.nl/nl/ } \\
\text { ExpertisesDienstverlening/Onderzoeksinstituten/ } \\
\text { Central-Veterinary-Institute/Publicaties-CVl/ } \\
\text { MARAN-Rapporten.htm }\end{array}$ & CLSI \\
\hline Germany & $\begin{array}{l}\text { German Resistance Monitoring in Veterinary Medicine } \\
\text { (GERM-Vet) }\end{array}$ & http://vetline.de/17079309/150/3130/69483 & CLSI \\
\hline Canada & $\begin{array}{l}\text { Canadian Integrated Program for Antimicrobial } \\
\text { Resistance Surveillance (CIPARS) }\end{array}$ & $\begin{array}{l}\text { http://www.phac-aspc.gc.ca/cipars-picra/ } \\
\text { index-eng.php }\end{array}$ & CLSI \\
\hline Italy & $\begin{array}{l}\text { Italian Veterinary Antimicrobial Resistance Monitoring } \\
\text { programme (ITAVARM) }\end{array}$ & http://195.45.99.82:800/pdf/itavarm.pdf & CLSI \\
\hline Japan & $\begin{array}{l}\text { Japanese Veterinary Antimicrobial Resistance } \\
\text { Monitoring programme (JVARM) }\end{array}$ & $\begin{array}{l}\text { http://www.maff.go.jp/nval/tyosa_kenkyu/taiseiki/ } \\
\text { monitor/e_index.html }\end{array}$ & $\begin{array}{l}\text { JSC until } 2000 \\
\text { CLSI after } 2000\end{array}$ \\
\hline Sweden & $\begin{array}{l}\text { Swedish Veterinary Antimicrobial Resistance Monitoring } \\
\text { programme (SVARM) }\end{array}$ & http://www.sva.se/en/antibiotika/svarm-reports & SRGA \\
\hline Spain & $\begin{array}{l}\text { Red de Vigilancia de Resistencias Antimicrobialas en } \\
\text { Bacterias de Origen Veterinario (VIV) }\end{array}$ & $\begin{array}{l}\text { http://racve.es/publicaciones/red-de-vigilancia- } \\
\text { veterinaria-de-resistencias-a-antimicrobianos/ }\end{array}$ & CLSI \\
\hline Norway & $\begin{array}{l}\text { Norwegian Surveillance System for Antimicrobial Drug } \\
\text { Resistance (NORM-VET) }\end{array}$ & https://www.vetinst.no & $\begin{array}{l}\text { MIC based } \\
\text { automated system }\end{array}$ \\
\hline Australia & $\begin{array}{l}\text { Pilot surveillance program for antimicrobial resistance } \\
\text { in bacteria of animal origin }\end{array}$ & $\begin{array}{l}\text { http://www.health.gov.au/internet/main/publishing. } \\
\text { nsf/Content/health-pubhlth-strateg-jetacar-pdf- } \\
\text { amrstrategy_affa.htm }\end{array}$ & CLSI \\
\hline Finland & $\begin{array}{l}\text { The Finnish Veterinary Antimicrobial Resistance } \\
\text { Monitoring and Consumption of Antimicrobial Agents } \\
\text { report (FINRES-VET) }\end{array}$ & $\begin{array}{l}\text { https://www.evira.fi/globalassets/tietoaevirasta/ } \\
\text { julkaisut/julkaisusarjat/elaimet/finres_ } \\
\text { vet_2007_2009.pdf }\end{array}$ & CLSI \\
\hline Colombia & $\begin{array}{l}\text { Colombian Integrated Program for Antimicrobial } \\
\text { Resistance Surveillance (COIPARS) }\end{array}$ & https://www.ncbi.nlm.nih.gov/pubmed/25903494 & CLSI \\
\hline Mexico & Pilot Integrated Food Chain Surveillance System & $\begin{array}{l}\text { https://www.ncbi.nlm.nih.gov/pubmed/18325258 } \\
\text { https://www.ncbi.nlm.nih.gov/labs/ } \\
\text { articles/22870938/ }\end{array}$ & CLSI \\
\hline 28 European countries & $\begin{array}{l}\text { Monitoring and analysis of food-borne diseases in } \\
\text { Europe (EFSA) }\end{array}$ & $\begin{array}{l}\text { https://www.efsa.europa.eu/en/efsajournal/ } \\
\text { pub/4380 }\end{array}$ & CLSI \\
\hline $\begin{array}{l}\text { Pan-European (Denmark, Belgium, } \\
\text { The Netherlands, The UK, Ireland, } \\
\text { Germany, France, Italy, Spain, } \\
\text { Poland, Hungary, The Czech } \\
\text { Republic) }\end{array}$ & $\begin{array}{l}\text { Centre Europeend' Etudes pour la Sante Animale } \\
\text { (CEESA VetPath) }\end{array}$ & http://www.ceesa.eu/ & CLSI \\
\hline
\end{tabular}

JSC, Japanese Society for Chemotherapy; CLSI, Clinical and Laboratory Standards Institute; SRGA, Swedish Reference Group for Antibiotics.

surveillance programs which monitors resistance in non-human zoonotic Salmonella (AFSSA, Paris), and in bovine pathogenic strains by collecting resistance data from local public veterinary diagnostic laboratories (63).

The Spanish government established Red de Vigilancia de Resistencias Antimicrobialasen Bacterias de Origen Veterinario which studies the resistance pattern in microbial strains from sick, healthy, and food animals (64). Additionally, the Veterinary Monitoring of Antimicrobial Resistance (VAV) program has also been established for resistance surveillance and monitoring in Spain (65). In UK, the Department for Environment, Food and Rural Affairs compiles AMR data in Salmonella spp. The Canadian Integrated Program for Antimicrobial
Resistance Monitoring Surveillance was designed in light of a 2002 report from the Advisory Committee on Animal Uses of Antimicrobials, and Impact on Resistance and Human Health (66). In Asia, the Japanese Veterinary Antimicrobial Resistance Monitoring system was initiated in 1999, and the Korean Nationwide Surveillance of Antimicrobial Resistance was established in 1997 in South Korea (67).

In Indian context, there are no regulations for the use of antibiotics in food animals. The Global Antibiotic Resistance Partnership (GARP) was established in the year 2009 to develop actionable policy recommendations for spread of AMR, specifically relevant to low and middle-income countries, including India. In 2011, the India working group report of GARP described 
the situation of antibiotic usage and emerging resistance and recommended short and long-term actions. The working group recommended establishment of national antibiotic resistance and usage surveillance system, as well as monitoring changes over time. Due to lack of nationwide surveillance mechanism, resistance has gone largely unnoticed in India. However, antibiotic usage trends in India has been increasing steadily, for instance the units of antibiotics sold increased by about 40 per cent between 2005 and 2009 (7). Although increased consumption of antibiotics cannot be directly correlated to developing resistance, their inappropriate use can be. A policy paper of Ministry of Health and Family Welfare, India described means for restraining resistance through minimizing and ensuring rational antibiotic use in animals raised for human consumption; improved surveillance; exploring new drugs; and developing and implementing standard antibiotic policy (68).

Although there is no national database on AMU surveillance in India, few independent studies has been carried out in this regard. In one such study, a very high dependence over flouroquinolones as compared to other antibiotics was reported (69). Moreover, it was observed that the resistance pattern among pathogens differs regionally and data from various studies when combined and evaluated revealed that there is definite resistance to commonly used antibiotics in the pathogens implicated in the disease (Salmonella spp., Shigella spp., E. coli, Klebsiella spp., Vibrio cholerae, S. aureus, Neisseria spp., Klebsiella spp., Mycobacterium tuberculosis, and other strains) (69). It was also reported that Gram-negative bacteria consisting of Pseudomonas, Acinetobactor, Klebsiella, E. coli, and Enterobacter spp. were resistant to carbapenems, aminoglycosides, fluoroquinolones and third-generation cephalosporins (70). Recently, some newer resistance mechanisms such as the metallo-beta-lactamase NDM-1 have also been witnessed $(71,72)$. Such resistance mechanisms can further challenge efforts made toward management of AMR.

\section{STRATEGIES FOR THE PREVENTION AND CONTAINMENT OF AMR}

Global co-operative efforts are warranted at individual, community, local, regional, national, and international level to address AMR. In essence, all strategies should target at optimizing the antibiotic usage, minimize un-intended interaction between pathogenic microorganism and antibiotics, limiting the spread of resistant strains, and treating infections with judicious use of antibiotic to affect cure (73). In order to meet this goal, a Tripartite Alliance was formed between the WHO, FAO, and OIE with One Health approach. The tripartite alliance published the Global Action Plan on AMR in 2015. Likewise, FAO also launched its AMR Strategy in 2016 to back the proper execution of the WHO Global Action Plan in food and agricultural sectors (74). The WHO Global Action Plan emphasizes on increased awareness and understanding on AMU and associated AMR; build up knowledge regarding AMR through proper surveillance and research; optimal and rational use of antibiotics; lowering the incidence of infectious diseases; and on organizing resources, research, and development for proper integrated prevention and containment of antibiotic resistance (75).

Management of AMR in both human and veterinary pathogens requires ideal and concerted action of researchers, policy makers, veterinarian(s), industrialists, and also the end users. Besides development of newer and potent antimicrobials, possible intervention measures that may help in keeping a check at AMR have been compiled in Figure 3. Foremost is the check on AMU through strict legislation and monitoring on over-thecounter without prescription sales. Financial incentives to both the prescriber and dispenser leading to irrational usage needs to be strictly regulated. Periodic updation of standard treatment guidelines into more simple, locally relevant, evidence based, and easy to access documents is essential. Some motivational measures, such as pay for performance policy should be implemented by government authorities along with unbiased audit feedback mechanism on drug prescribing rates of individual practitioners and health-care facilities. Infection control interventions need to be re-assessed and improved. National task forces with a farreaching inter-sectoral coordinating role, involving all relevant stakeholders are desired. Such task forces should outline annual action plans and milestones in different areas such as surveillance, regulation, treatment guidelines, infection control, education, and awareness (76).

\section{ALTERNATE MANAGEMENT STRATEGIES}

Spread of AMR in conjunction with slow emergence of novel antibiotics; have created a deficit of effective therapies against microbial disorders. Presently, the mobility of a newer drug from the phase of discovery, clinical efficacy, and safety assessment to approval is estimated to cost more than double $(77,78)$. Therefore, finding and introducing novel antibiotics has become more challenging and antimicrobial research no longer remains an attractive option for investors seeking quick and substantial returns. It is high time for more innovative and bold solutions to curtail resistance to antibiotics and speed-up the discovery and introduction of new, safe, resistance-free and economical alternatives to antibiotics (49). Ideal alternatives to antibiotics should be non-toxic with easy elimination from the body, stable through gastrointestinal transit, easily decomposed and environment friendly, selectively active against pathogens with minimum or no effect over resident gut flora, improve feed efficiency and promote animal growth, and above all free from resistance (79). Novel strategies, showing promise toward replacing and/or serving as an adjunct to current day antibiotics and displaying activity against MDR strains have been discussed in detail below in this section (Figure 4).

\section{VACCINES}

Vaccination is used as a powerful strategy for prevention and even eradication of infectious diseases. Vaccination is promising in eradicating many diseases worldwide, viz., small pox and polio, successfully and, thus, could be used to restrain AMR bacteria especially having wide impact on human and animal health. The application of vaccines as a valid alternative therapeutic to 


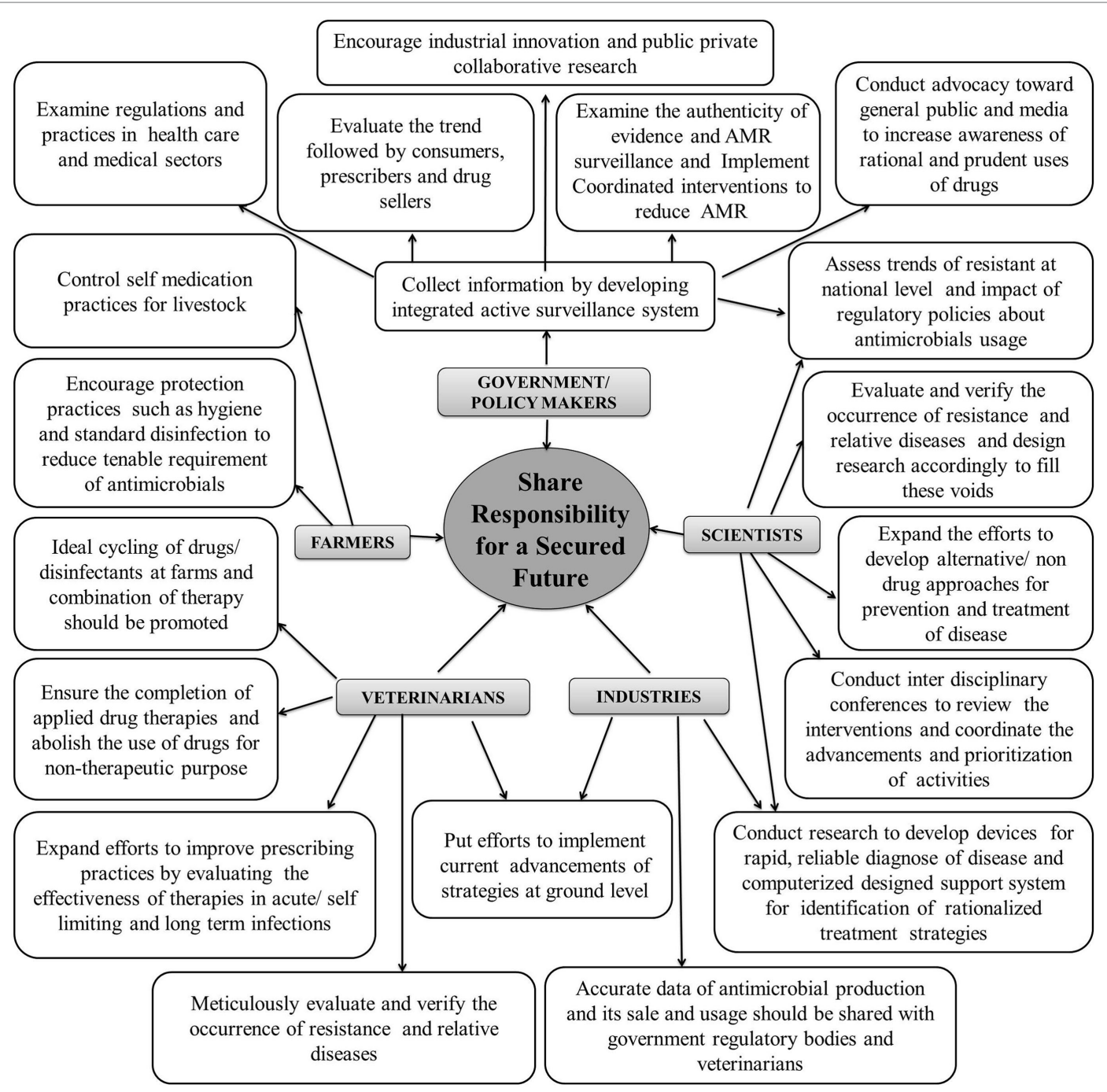

FIGURE 3 | Collaborative meticulous approaches to mitigate antimicrobial resistance (AMR).

antibiotics has attracted much attention due to the fact that resistance is not observed against vaccines, because of its characteristic features and mechanism of action (80). Recombinant vaccines generally possess multiple immunogenic epitopes, thereby requiring multiple mutations for allowing resistance development and single mutation vaccines are not acceptable clinically. Vaccines developed though recombinant methods restrict bacterial replication, prevent selection of variants, and overcome selection pressure in environment (Figure 5). Vaccines are biotic preparations that develop acquired immunity against a selective organism/target (Figure 4) (81-83). In general, vaccines falls under three categories, viz., killed/inactivated vaccines (antigens with adjuvants); live/attenuated vaccines (live vaccines), and recombinant vaccines (subunit antigens or genetically engineered organisms). In veterinary practice, multivalent/ multicomponent vaccine approach has been mostly explored. Veterinary vaccines are ideal candidate for animal health and welfare and for food production as they help in preventing the infection; reducing consumption of antimicrobial drugs; enhancing food productivity; and mitigating the impacts of antibiotic resistance. Vaccination too lessens the transmission of zoonotic and foodborne infections to humans $(49,84)$.

Keeping in mind the utility of vaccines over antibiotics, R\&D is being undertaken to produce advanced vaccines through recombinant DNA technology. Recombinant veterinary vaccines are classified into three groups, i.e., DNA or RNA vaccines, subunit recombinant vaccines, and vectored vaccines. Recombinant vaccine development involves cloning of DNA fragment into a vector. Recombinant DNA or RNA vaccines results in expression of pathogen specific proteins, while, in subunit vaccines a recombinant protein is generated in laboratory and injected into the host. Recombinant vector vaccines use an attenuated bacterium or virus to either multiply and express the antigen within the host or introduce DNA in the host cells (85). Further advancement in genetic engineering and bioinformatics permits the identification and synthesis 


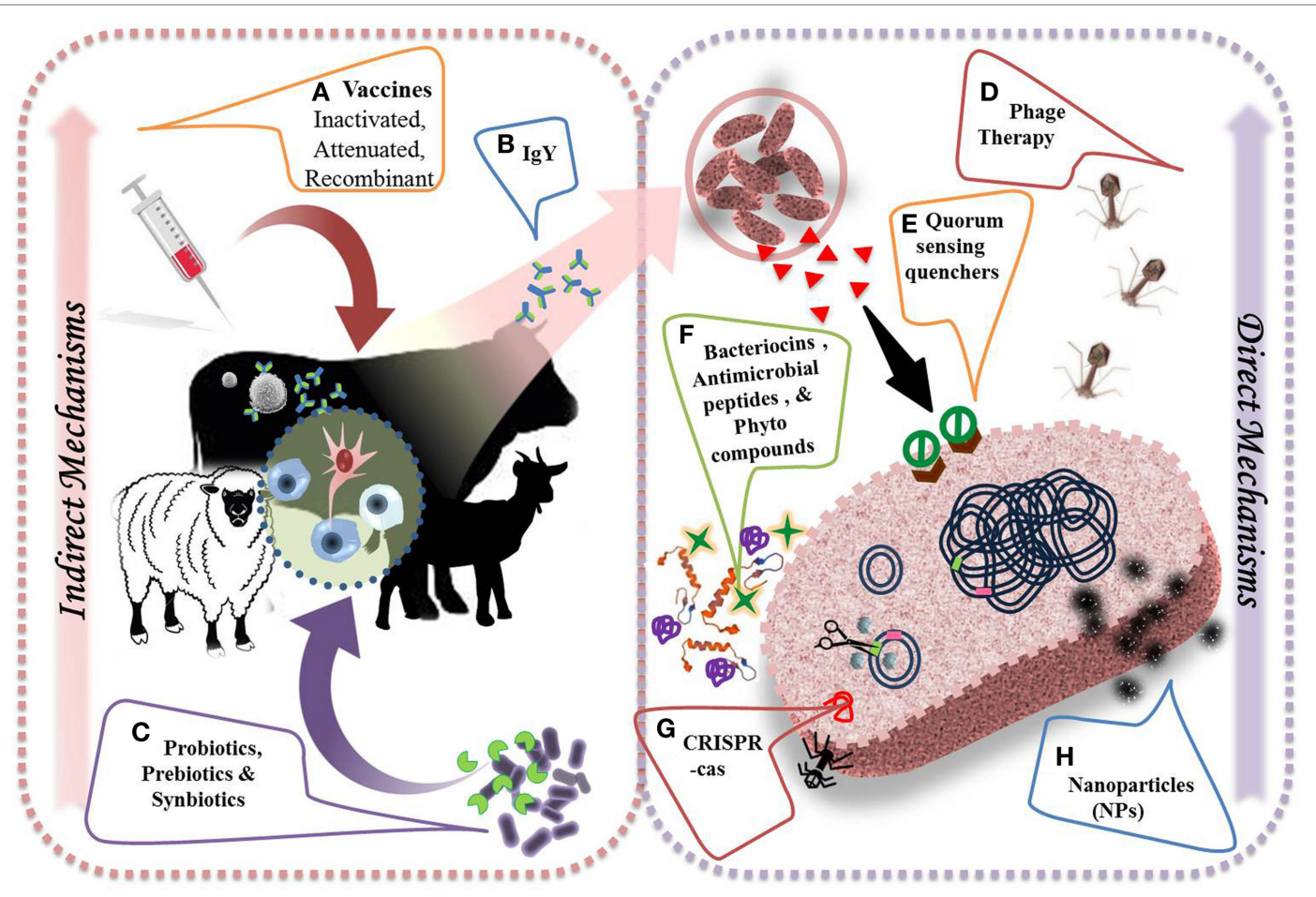

FIGURE 4 | Alternative strategies to combat antimicrobial resistance and their direct and indirect mechanisms of action. (A) Vaccination helps in preventing the course of infections by evolving immune cells (i.e. B cells $\mathbf{s}$, T cells $\bullet$ ) to develop an adaptive immunity by producing specific antibodies (ג) against important pathogens. (B) Chicken egg yolk antibodies provide effective treatment approach against several viral and bacterial diseases. (C) Probiotics ( $)$, prebiotics ( $)$ ), and synbiotics improve general health by selectively stimulating innate immune cells (†)). (D) Lytic bacteriophage or their purified gene products could be used to treat sepsis and few bacterial infections. (E) Quorum sensing quenchers (D) could control virulence of pathogens by inhibiting the binding of auto-inducers ( $\nabla$ ) to respective receptors. (F) Antimicrobial peptides $(\$)$, bacteriocins $\left(\begin{array}{c}(\xi) \\ (\end{array}\right)$, and phytocompounds $(+)$ directly inhibit the bacterial growth by acting on bacterial cell membrane. (G) Modified CRISPR-Cas approach targets resistance genes in pathogens and reverse the selective pressure of resistance. (H) Metal-based nanoparticles $(*)$ ) help in blockage of enzyme pathways, alteration of cell wall, and nucleic material pathways.

of epitopes possessing ability to trigger the immune response, resulting in the development of recombinant vaccines. Such recombinant vaccines provide targeted immunity and eliminate the use of attenuated infectious agents, ensure safety, and early onset of immunity (85). These vaccines comprise of minimum of one modified antigen having ability to induce an immune response against targeted pathogens upon co-administration with adjuvants or plasmids (86).

The first DNA vaccine for veterinary application was licensed in 2005, against the Equine West Nile Virus $(87,88)$. Subunit vaccines, namely Gavac and Tick GUARD, developed by Heber Biotec and Fort Dodge too have been approved for commercial use in cattle against Ripcephalus (Boophilus) microplus. In India, Shakya et al. (89) characterized recombinant Subolesin, having 44 and $37.2 \%$ vaccine efficacy against female ticks in crossbred cattle male calves after first and second challenges, respectively. The subolesin ortholog of Hyalomma anatolicum and $R$. (B) microplus was reported to be highly conserved across different Indian strains, having over $50 \%$ of sequence homology at the amino acid level. HIDATIL EG95, a subunit vaccine, is available for protecting sheep and goats against Echinococcus granulosus (85). Leish-Tec is one of the commercially available recombinant vaccines against protozoans (90). Among vectored vaccines, cattle vaccinated with a BCG strain overexpressing the Ag85B antigen (protein found on the bacterial surface) displayed enhanced protective immune responses against Mycobacterium bovis (91). Currently, most of the practiced bacterial vaccines include live attenuated and inactivated or killed microbial strains, with varying degrees of efficacy, e.g., RB-51, a commercially available bacterial vaccines used to cure Brucella abortus in cattles (49). Regarding commercialization of veterinary vaccines in India, till date no recombinant vaccine has been found to satisfy regulating agencies and so has not been in the Indian market.

In the present scenario, research is inclined toward exploring prophylactic vaccines as therapeutics. Bacterin, a suspension of killed or attenuated bacteria is active against multiple pathogens (92). Globally, bovine mastitis is a major concern for dairy farming. S. aureus is one of the organisms associated with mastitis. A number of approaches, such as whole organism vaccines, live attenuated $S$. aureus, capsular polysaccharide-protein conjugate vaccines, DNA vaccines encoding clumping factor A, and recombinant $S$. aureus-mutated enterotoxin type $\mathrm{C}$ have been explored for vaccine development against $S$. aureus (93). Earlier, Sayed et al. (94) studied the anti-mastitis efficacy of a locally prepared polyvalent vaccine (Montanide ISA-206 adjuvanted inactivated polyvalent vaccine) comprising of $S$. aureus, Streptococcus 


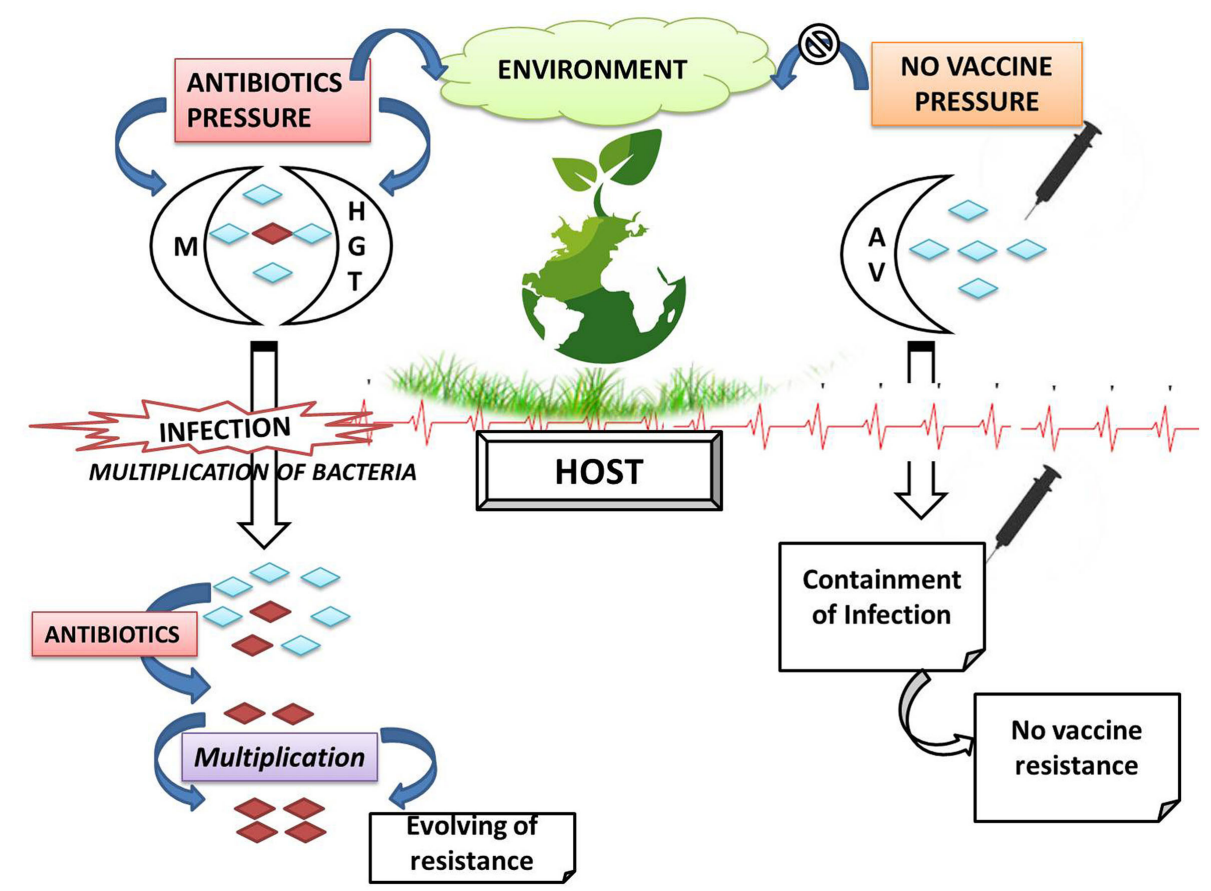

FIGURE 5 | Comparative resistant phenomenon with respect to antibiotics and vaccines (M, mutation; HGT, horizontal gene transfer; AV, antigenic variation; $\diamond$, antibiotic-resistant bacteria; $\diamond$ antibiotic-sensitive bacteria).

agalactiae, and E. coli. The study reported an improved immune response in the vaccinated group. Additionally, bacterial strains, such as Salmonella Typhimurium and lactic acid bacteria (LAB), can be explored as a vehicle for vaccine delivery due to specific targeting and activation of APCs (antigen-presenting cells) $(48,88,95)$. Cloven-hoofed animals including dairy animals, viz., cattle, buffalo, sheep, and goat, are susceptible to foot-andmouth disease (FMD), caused by a fast-replicating FMD virus. Inactivated whole virus vaccines are currently being explored for preventing FMD; however, faces several short-falls including risk of escape of live virus and requirement of costly biocontainment facilities. Virus-like particles, being structurally similar to virus, but being non-infectious, safe, and having good immunogenic properties are being explored as an alternate to whole virus vaccines. Recently Kumar et al. (96) constructed and characterized recombinant adenovirus expressing capsid proteins of Indian FMD virus strain O/IND/R2/75 to a high titer. Later, Eri silkworm larvae were explored for production of VLPs of FMD O/ IND/R2/75 using recombinant baculovirus encoding polyprotein of FMD virus (97).

Although vaccination has emerged as a powerful tool against drug resistance strains, several evolving strains may escape immunity induced by vaccine administration. Hence, a regular update on vaccine strain is warranted (98). Ideally, it could be possible to develop and use vaccines against an etiological agent having reportedly high endemicity, having stable genetic composition and where chances of AMR are very high. Though this strategy will involve huge expenditure as development of vaccine against a homologous strain could be expensive, it could provide for an alternative we look for. Advanced recombinant vaccines are undoubtedly the future of addressing infectious disease in dairy animals. There is a need to develop safer, potent, and better characterized vaccines with broader protection against multiple pathogens. However, developed vaccines needs to qualify rules and registration guidelines for recombinant vaccines. The biological characteristics of recombinant virus must be documented for proper risk assessment associated with its use in target species. Safety characteristics of such vaccines must be ascertained for both host and environment before field trails can be authorized (99).

\section{PHYTOCOMPOUNDS}

Since time immemorial, plants have been indispensable sources of traditional medicine for the management of human and livestock health. Livestock farmers, particularly from rural areas consult or visits traditional practioners for the treatment of various animals disorders in developing countries (100). Traditional remedies, mainly comprising of plant components/extracts, being natural, non-toxic, inexpensive, and easily available are readily accepted by the farming community. Ethnoveterinary medicine refers to the holistic and interdisciplinary study of traditional knowledge, practices, and methods pertaining to animal health care (101). Plants possess multifunctional properties, primarily linked to the presence of varied bioactive secondary metabolites or phytocompounds, viz., glycosides and alkaloids (alcohols, aldehydes, esters, ethers, ketones, lactones, etc.), anthocyanins, coumarins, flavonoids, phenolics (tannins), saponins, and terpenoids (mono and sesquiterpenes, steroids, 
etc.) (102). Several plant components are incorporated to animal feed as growth promoters and health protectants $(79,103,104)$. Hence, any potent phytocompound displaying broad-spectrum antimicrobial activity can serve as an ideal alternative to conventional veterinary antibiotics $(105,106)$.

Plant extracts or phytobiotics are mainly explored in animal nutrition for their diverse pharmacological activities, such as antimicrobial, anti-inflammatory, antioxidative properties, etc. Plant extracts, such as tea tree oil and its active component, terpinen-4-ol, have demonstrated efficacy in bovine mastitis treatment. Terpinen-4-ol inhibits pro-inflammatory cytokine, upregulates anti-inflammatory cytokine expression, and displays tissue healing characteristics (107). Ghosh et al. (108) documented the antioxidant, anti-inflammatory, hypoglycemic, anticancer, and antimicrobial properties of diferuloylmethane, a polyphenol isolated from turmeric (Curcuma longa) rhizomes. Brooks et al. (109) reported enhanced expression of $\mathrm{CD}^{+}$and $\mathrm{CD}^{+} \mathrm{T}$ cells in neonatal calves fed with extracts from Morinda citrifolia. The plant extracts also possess bactericidal and immunomodulatory properties, and positively impacts animal growth performance (110). Extracts from Allium sativum also exhibits antibacterial, anti-diarrheal, anti-inflammatory, and immune-modulatory properties (Figure 4). In a trial involving neonatal calves, allicin delayed the onset of Cryptosporidium parvum-induced diarrhea. Similar findings were recorded in pre-ruminant calves $(111,112)$.

Earlier, Luseba and Tshisikhawe (113) reviewed the available data on medicinal plants used for the treatment of cattle disorders in South Africa. Whole plant, leaves, and root extracts from Asparagus falcatus, Tagetes minuta, Diospyro slycioides, and Vernonia corymbosa have been shown to control ticks and worms in cattle. Elephantor rhizaburkei bulb and Xanthocersis zambesiaca bark manages diarrheal problems in cattle. In another study, Panda and Dhal (114) reviewed the veterinary medicinal plants of Odisha, India. Various plants and their components have proposed role in management of cattle diseases, including diarrhea, lactation, and foot-and-mouth disorders. On similar pattern, Narayana and Rao (101) reviewed the ethnomedicinal plants of Andhra Pradesh, India. They documented several preventive and therapeutic roles of stem bark, leaves, rhizome, and whole plant extracts of several plants for curing anthrax, dysentery, wounds, ephemeral fever, FMDs, bronchial disorders, gout/inflammation, fractures, etc. Earlier, Dhama and coworkers (102) reviewed and compiled the available literature on antibacterial activity of medicinal plants and herbs. Few of the follow up studies have been recorded in Table 2 .

Besides other plant components, use of plant essential oils (EOs) for the management of livestock is becoming a common practice. Nanon et al. (130) documented that EOs from lemon grass and mixture of garlic and ginger can be explored as rumen modifier, resulting in improved feed digestion, particularly of roughage feeds. A recent study conducted by Jeshari et al. (131) showed that supplementing starter diets with a mixture of EOs from Rosmarinus officinalis L., Zataria multiflora Boiss, and Mentha pulegium L. positively impacted the growth performance of suckling calves. Plant-food by-products are also being utilized as animal feed $(132,133)$. Pomegranate byproduct extracts act as a good source of phenolics, having inherent antioxidant, antiinflammatory, and antimicrobial activity (134). In past, several phyto-compunds have displayed promising antibacterial activity against MDR strains. To name a few, extacts from 18 herbal plants considerably limited the growth of MDR Acinetobacter baumannii under in vitro conditions (135). Recently, phytocompounds have been reported to display potent antibacterial activity against MRSA (136) and extended-spectrum beta-lactamase-producing bacteria $(137,138)$. Interest toward adopting plant-based compounds as therapeutics is gaining interest. However, most of the results are coming from in vitro studies and required further in vivo studies for validation.

The mechanisms underlying the antibacterial properties of phytocompounds along with their impacts on pathogen virulence, and other host factors have been reviewed in detail earlier by Dhama et al. (102). In brief, the antimicrobial activity, whether bactericidal or bacteriostatic, may be mediated through enhanced immunity, proliferation of $\mathrm{B}$ and $\mathrm{T}$ cells, stress amelioration, cytokine regulation, suppressing free radicals, inhibition of prostaglandin biosynthesis, decreased production of inflammatory molecules (histamine, serotonin), enhanced cortisol activity, improved blood circulation promoting toxin removal from body, NF- $\kappa \mathrm{B}$ downregulation, damage to cell membrane with loss of cytoplasmic contents and electrolytes, quorum sensing (QS) inhibition with minimized synthesis of LasA protease, LasB elastase and $\mathrm{N}$-acyl homoserine lactone (AHL) molecules, and promoting phagocytosis, etc. (102).

The main constraints associated with application of phytocompounds in animal husbandry, particularly dairy animals is its being a complex blend of bioactive compounds and variation in composition due to several biological, processing, and storage factors (139). Further, the units of application are not standardized. Future research targeting phytocompounds purification, understanding their mode of action, standardizing appropriate units of administration, compatibility with diet, toxicity, safety and stability assessment, as well as their pharmacodynamics and pharmacokinetic properties is required for establishing them as an effective alternate to antibiotics.

\section{PROBIOTICS, PREBIOTICS, AND SYNBIOTICS}

The ban of dietary antimicrobial agents attracted a great deal of attention toward the application of probiotics, prebiotics, and synbiotics for production of safe food along with improved gut health (140). With the advent of new antibiotic resistance strains, probiotic strains are gaining popularity in both medical and livestock sector (141-143). In few cases, probiotics and direct-fed microbials (DFMs) have been employed as animal feed that acts as an alternative to antibiotics, as growth promoters, and also control enteric pathogens (144). Several reports propose substitution of antibiotics with probiotic strains as growth promoters in livestock animals $(144,145)$. Probiotics as a microbial food supplement helps in maintaining the intestinal microbial balance of host and also act as immune-stimulant (Figure 4) $(146,147)$. Probiotic additives have been explored to improve animal health 
TABLE 2 | Plant extracts explored against various diseases causing bacterial pathogens in dairy animals.

\begin{tabular}{|c|c|c|c|c|c|}
\hline Scientific name (common name) & $\begin{array}{l}\text { Plant part } \\
\text { used }\end{array}$ & Type of extracts & $\begin{array}{l}\text { Pharmacologically active } \\
\text { phytoconstituents }\end{array}$ & Antibacterial activity against & Reference \\
\hline Senna macranthera & Roots & Dichloromethane & $\begin{array}{l}\text { Emodine, physione, and } \\
\text { chrysophanol }\end{array}$ & Staphylococcus aureus & $(115)$ \\
\hline $\begin{array}{l}\text { Combretum molle (velvet leaved } \\
\text { Combretum), Xanthium strumarium } \\
\text { (Cockleba) }\end{array}$ & $\begin{array}{l}\text { Stem, bark, } \\
\text { leaves }\end{array}$ & $95 \%$ ethanol & - & S. aureus and Streptococcus agalactiae & $(116)$ \\
\hline Allium sativum (garlic) & Cloves & Juice & - & Cryptosporidium sp. & $(117)$ \\
\hline Neoglaziovia variegata & Leaves & $\begin{array}{l}\text { Hexane and } \\
\text { ethanolic }\end{array}$ & - & Rhipicephalus (Boophilus) microplus & $(118)$ \\
\hline $\begin{array}{l}\text { Psidium guajava (guava) } \\
\text { T. foeum-graecum (fenugreek) }\end{array}$ & Leaves, seeds & Methanol & - & $\begin{array}{l}\text { S. aureus, Escherichia coli, Pseudomonas } \\
\text { aeruginosa, Salmonella sp. }\end{array}$ & $(119)$ \\
\hline Thalictrum minus & Roots & $\begin{array}{l}\text { Dichloromethane } \\
\text { and methanol }(1: 1)\end{array}$ & $\begin{array}{l}\text { Benzylisoquinoline alkaloids } \\
\text { (5'- hydroxythalidasine, } \\
\text { thalrugosaminine, } \\
\text { O-methylthalicberine) }\end{array}$ & $\begin{array}{l}\text { Staphylococcus xylosus, S. lentus, } \\
\text { S. equorum, Enterococcus faecalis, E. coli }\end{array}$ & $(120)$ \\
\hline Cinnamon cassia oil & - & - & - & $\begin{array}{l}\text { S. aureus, S. epidermidis, S. hyicus, } \\
\text { S. xylosus, E. coli }\end{array}$ & $(121)$ \\
\hline Holarrhena antidysenterica & Bark & Ethanolic & - & E. coli & $(122)$ \\
\hline $\begin{array}{l}\text { A. sativum, Bunium persicum, } \\
\text { Oryza sativa, Triticum aestivum }\end{array}$ & $\begin{array}{l}\text { Bulb, seeds, } \\
\text { fruits }\end{array}$ & Methanolic & Alkaloids & S. aureus, E. coli, K. pneumoniae & $(123)$ \\
\hline $\begin{array}{l}\text { Dalbergia retusa, Crescential alata, } \\
\text { P. guajava, Vitex mollis }\end{array}$ & Leaves & Methanolic & - & Methicillin-resistant S. aureus & $(124)$ \\
\hline Acacia nilotica, Tetradenia riparia & Bark, flower & Acetone & - & $\begin{array}{l}\text { S. aureus, Streptococcus uberis, } \\
\text { S. agalactiae, K. pneumoniae, E. coli, } \\
\text { P. aeruginosa, P. mirabilis }\end{array}$ & $(125)$ \\
\hline $\begin{array}{l}\text { Salvadora persica, Colophospermum } \\
\text { mopane, Dichrostachys cinerea }\end{array}$ & $\begin{array}{l}\text { Leaves, bark, } \\
\text { roots }\end{array}$ & Methanolic & - & S. aureus, E. coli & $(126)$ \\
\hline Aloe vera, Curcuma longa & - & $\begin{array}{l}\text { Aqueous, ethanol, } \\
\text { and ethyl acetate }\end{array}$ & - & E. coli, S. aureus, P. aeruginosa & $(127)$ \\
\hline $\begin{array}{l}\text { Evernia prunastri (plum lichen), } \\
\text { Artemisia absinthium (Absinthe } \\
\text { wormwood), Lavandula angustifolia } \\
\text { (Lavender) }\end{array}$ & - & $96 \%$ Ethanol & - & $\begin{array}{l}\text { S. aureus, S. xylosus, S. intermedius, } \\
\text { S. chromogenes, S. hyicus, Vibrio fluvialis, } \\
\text { Serratia liquefaciens, E. coli, Lactococcus } \\
\text { lactis, Enterobacter intermedius, Bacillus } \\
\text { cereus, Yersinia ruckeri, Aeromonas } \\
\text { hydrophila, Kytococcus sedentarius }\end{array}$ & $(128)$ \\
\hline Panicum turgidum (Thummam) & - & Aqueous & - & Streptococcus pyogens, Candida albicans & $(129)$ \\
\hline
\end{tabular}

and productivity by stimulating healthy intestinal microbial ecosystem $(148,149)$, promoting digestion, nutrient absorption, and bioavailability (150), preventing enteric pathogens colonization (151), restoring gut microflora (152), lowering $\mathrm{pH}$, and improving mucosal immunity (149). Therefore, probiotics can act as an ideal candidate to improve the general health and productivity of ruminants (153).

It is quite evident from available data that probiotics have direct antagonistic activity against varied number of resistant strains. Jamalifar et al. (154) reported strong antagonistic activity of Lactobacillus acidophilus fecal isolate against the MDR clinical isolate of Pseudomonas aeruginosa. On similar lines, Bifidobacterium pseudocatenulatum SPM1309 was shown to inhibit MDR P. aeruginosa and A. baumannii (155). Lactobacillus casei strain exhibited strong activities against MDR Shigella strain (156). Strains of L. casei also displayed strong inhibitory effect against MDR E. coli (157). In a recent study, Kumar et al. (97) documented antimicrobial activity of Lactobacillus plantarum and L. acidophilus against MDR entero-aggregative E. coli. Ripamonti and coworkers reported inhibitory effect of a speciesspecific probiotic formulation against MDR E. coli isolates from calves (158). Lactobacillus sp., Bacillus sp., Enterococcus sp., Bifidobacterium sp., Lactococcus sp., Pediococcus sp., Streptococcus sp., Propionibacterium sp., Saccharomyces sp., and Aspergillus sp. are mainly used as candidate probiotics in livestock and animal husbandry, either as feed additive or in some other form $(79,153$, 159, 160).

Gulbe et al. (161) documented the synergistic antagonistic effect of Lactobacillus helveticus and lysozyme against mastitiscausing staphylococci. Probiotic strains have also been reported to mitigate E. coli O157:H7 in cattle. A probiotic mix of Streptococcus bovis and L. gallinarum resulted in reduced E. coli O157 shedding in experimentally infected calves (162). A blend of L. acidilactici and Pediococcus sp. of bovine origin was shown to 
directly inhibit E. coli O157:H7 under in vitro conditions (163). Lactobacillus sp. based DFMs, currently marketed as Bovamine ${ }^{\mathrm{TM}}$ and BovamineDefend ${ }^{\mathrm{TM}}$ are being widely explored for reducing E. coli $\mathrm{O} 157: \mathrm{H7}$ in cattle (144).

Prebiotics are the non-digestible food ingredients that are selectively metabolized by the gut microbial inhabitants. They support selectively proliferation of intestinal bacteria, promote immune response, display antimicrobial activities, and deliver beneficial health effect to host. The most commonly used prebiotics are carbohydrate substrates, i.e., oligosaccharides, polysaccharides, polyols, protein hydrolyzates, etc. $(79,149)$. Prebiotics have long history of use as feed additives. Some oligosaccharides have been proposed to have specific health benefits in calves. To name a few, mannan-oligosaccharide, a complex mannose sugar is believed to block pathogen colonization in the intestinal tract. It has been observed that few prebiotics endow competitive advantage to selective beneficial gut flora, i.e., probiotic strains such as, Bifidobacterium sp., Lactobacillus sp., that are known to act antagonistically against pathogens $(164,165)$. Fructooligosaccharide along with spray-dried bovine serum minimized the incidence and severity of enteric disease in calves (166). This attribute has been linked to the pathogen exclusion properties of fructooligosaccharide, wherein the E. coli and Salmonella adhesion to the intestinal epithelium is restricted (167). The administration of oligosaccharides to weaned calves promotes desirable intestinal (rumen and/or lower intestine) community that prepares ground for improved growth performance at an older age. Celmanax, a commercial prebiotic for cattle prevent enterohemorrhagic E. coli colonization in the intestine (168).

A combinantion of probiotics and prebiotics, recognized as synbiotics is designed to avail health benefits in a highly targeted fashion (169). It has been found that synbiotic supplementation to animal feed augments the lactate and antibody production, lowers intestinal $\mathrm{pH}$, which alters the intestinal microflora, and minimizes harmful bacteria in the gut (170). Earlier, Bomba et al. (171) also reported synergistic role of synbiotics in reducing pathogenic bacteria in food animals. In an in vivo study, continuous oral co-administration of Bifidobacterium breve strain Yakult and galacto-oligosaccharide rendered protection against MDR A. baumannii and increased the survival rates of mice. Synbiotic treatment promoted the indigenous gut flora from pathogenic one, reduced endotoxin level and pathogen mediated damage, and rejuvenated the gut barrier function. No positive effects were recorded upon treatment with GOS alone (172). Continuous antibiotic treatment usually results in washing out of indigenous gut flora, which can be replenished with the concomitant administration of selective probiotic and prebiotic components.

Although the prospects of using pro-, pre-, and syn- biotics in dairy animals are bright, their current application is limited by paucity of studies answering the strain-specific activity of probiotic strains; variability within host animal species; age, diet, and physical condition of target animal; degree of the pathogen challenge and other stressors; dose and duration of administration, etc. All these factors need to be considered and standardized. Also there is a need to meticulously understand the safety characteristic of probiotic strains, especially with regard to possibility of transfer of resistance traits, and in immune-compromised subjects. Few recent studies have documented the resistance profile of Lactobacillus spp. strains from different origin (173). Naturally being safe and supported with current research findings, further involvement of omics tools will strengthen their candidature as a possible application in food animals, as a preventive and supportive therapy, as an adjunct to antibiotics or even as a safe alternate to current day antibiotics, reducing the AMU and associated resistance.

\section{BACTERIOCINS}

Bacteriocins are the ribosomally synthesized bacterial antimicrobial peptides (AMPs) that can kill or inhibit closely related bacterial strains (174). They are generally produced by a variety of Gram-positive bacteria and classified into two classes, i.e., class $I$, also called lantibiotics because they are heavily modified after translation to contain amino acids, such as lanthionine and B-methyllanthionine, and class II, heat-stable peptides, which are released without any posttranslational modifications (175). Most commonly, LAB are known to secrete bacteriocins, i.e., nisin (Lactococcus lactis), lactocin (Lactobacillus sakei), pediocin (Pediococcus acidilactici), acidocin (L. acidophilus), sacacin (L. sakei), plantaricin (L. plantarum), helveticin (L. helveticus), curvacin (L. curvatus), lactobin (L. amylovorus), etc. Bacteriocins produced by Gram-negative bacteria are colicins and microcins (E. coli). Among LAB bacteriocins, nisin is the most commonly explored $(176,177)$. Diverse classes of bacteriocins have varied mechanisms of action which are different from antibiotics (178). Applications of bacteriocins are widespread; ranging from treatment of topical and internal infections, food preservation and antimicrobial packaging.

The mechanism of action divides bacteriocins in to two distinct types; one those work on cell envelope and other those inhibit gene and protein expression (Figure 4). Several investigators have demonstrated that application of these bacteriocins with combination of antibiotics significantly improves the effectiveness of drugs. For instance, Tong et al. (179) have examined the minimum inhibitory concentration of 18 different antibiotics against Enterococcus faecalis and found that addition of nisin reduced the MIC values of all the tested drugs. In addition biofilm forming pathogens such as $S$. aureus, associated with bovine mastitis has also been mitigated with the combination of nisin and lysostaphin (180). Interestingly, McCaughey et al. (181) have reported that a $P$. aeruginosa-specific bacteriocin, pyocins S5, was effective at 100 -fold lower concentration than the most commonly used inhaled antibiotic tobramycin in a murine model.

Furthermore, bacteriocins based products are commercially available for the treatment of superficial and systemic bacterial infections and have several potential applications in the veterinary field also. For example, nisin based teat sanitizers, Amibicin $\mathrm{N}^{\circledR}$ (Applied Microbiology, Inc., New York, NY, USA), WipeOut $^{\circledR}$ Dairy Wipes, and Mast Out ${ }^{\circledR}$ (Immucell Corporation) are already in practice and serving as an effective alternative for the treatment of mastitis (182). Similarly, a teat dip containing 
lantibiotic, lacticin 3147 , is also available for therapeutic remediation of staphylococcal infection. This product has been proven significantly effective against $S$. aureus, $S$. dysgalactiae, and Streptococcus uberis (183). Likewise, two broad-spectrum peptides/bacteriocins, geobacillus I and geobacillus II, were characterized by Rea et al. (184) and were found to be very effective against $S$. dysgalactiae subsp. dysgalactiae. There are few other potential examples, such as nisin $U$, nisin Z, uberolysin, bacteriocin ST91KM, morricin 269, kurstacin 287, kenyacin 404, entomocin, Pep5, epidermin, epilancin K7, epicidin 280 and aureocins A70, A53, and 215FN, which have displayed potential activity against $S$. aureus and S. agalactiae (182, 185-189). Beside skin and udder infections, bacteriocins are also proven to be effective against a range of enteropathogens. Microcin C7 and Colicins $1 \mathrm{~b}$ and E1 from E. coli (190) as well as enterocin RM6 inhibits pathogenic enterobacteria, i.e., Enterobacter agglomerans, E. coli, K. pneumoniae, Morganella morganii, Salmonella enterica, Shigella flexneri and Yersinia enterocolitica (191).

Therefore, bacteriocins can be explored for controlling bacterial infections in livestock animals, including mastitis and other systemic infection, which could reduce the dependency on antibiotics for the treatment. However, the major concern regarding bacteriocin is their narrow spectrum efficacy along with insufficient toxicity data. Therefore, the future role of bacteriocins as an alternative therapy to classical antibiotics is still in its infancy. Moreover, the higher specificity of action of bacteriocins, especially against MDR strains is very encouraging. In future, the introduction of chemical and genetic engeneering in order to auspicious consideration of bacteriocins as a consistent treatment strategy will offer a strong solution for growing AMR problem.

\section{ANTIMICROBIAL PEPTIDES}

Antimicrobial Peptides, recognized as host defense peptides, are one among the leading alternatives to ongoing antibiotic therapy and are abundantly distributed in nature (192). They are ubiquitously present in all the organisms and possess varied structural and functional diversity and displays remarkable antimicrobial and immunomodulatory properties, which make them an ideal candidate for the development of novel therapeutics. AMPs may be either anionic (a small group present in ruminants, mainly rich in aspartate and glutamate) or cationic (a large group present in all domesticated animals). Cationic peptides may be linear, helical, proline-rich linear peptides, and cysteine-stabilized peptides with a $\beta$-sheet. Usually they exhibit broad-spectrum antimicrobial activity against bacteria and fungi (193). Further, based on the peptide synthesis machinery, AMPs may be either ribosomally (bacteriocins) or non-ribosomally (bacitracin, gramicidin, polymyxin, etc.) synthesized (79). These small polypeptides are amphipathic in nature and exhibit hydrophobic/cationic properties which promote their intercalation into the bacterial phospholipid bilayer, creating pores and resulting in osmotic lysis (Figure 4) (193). In addition, they have the capability to bypass the common resistance mechanisms employed against standard antibiotics. Besides carrying potent antimicrobial activities, AMPs promotes the nutrient digestibility, intestinal morphology, and beneficial gut microbiota, having overall positive effects on growth performance of animals (83). In one such study, AMPs, A3 and P5 (synthetic) and cecropin $\mathrm{AD}$ (artificial), positively regulated the growth performance of animals mediated through selection of beneficial gut microbiota (194). Ruminants possess vast array of AMPs that offers a natural innate barrier against microbial pathogens (195). In contrast to antibiotics, AMPs usually targets the host cells and prevents infection in an indirect mode, conferring an additional advantage over antibiotics (83).

It has been observed that AMP Esc-1a (1-21) $\mathrm{NH}_{2}$ has potent and rapid activity against bovine mastitis pathogen, $S$. agalactiae (196). Bovine AMPs (Peptide B/enkelytin) are well studied and exhibit potent antimicrobial efficacy. Processing of these peptides in brain plays an important role in neuro-immune responses to bacterial invasion; thereby acting as an important class of immune-modulatory peptides (197). Bovine AMP, Kappacin, was initially isolated from milk and cheese and is the cleavage product of caseinomacropeptide with no posttranslational modifications. It displays broad range of activity in a $\mathrm{pH}$-dependent manner $(198,199)$. Strub et al. (200) studied another bovine AMP, Chromacin, isolated from bovine chromaffin granules, which inhibits the growth of both Gram-positive and Gram-negative bacteria. Bacitracin methylene salicylic acid and bacitracin zinc had been approved in USA and China as feed additives (79). In an interesting study, Zhang et al. (201) observed that AMPs can be explored to overcome mastitis by applying recombinant DNA technology, which enables mammary cells to synthesize and secrete lactoferricin and tracheal antibacterial peptides, having role in management of mastitis. AMPs have also been screened for their antimicrobial potency against pathogens exhibiting multidrug resistance and had been proposed as an alternative to antibiotics in animal husbandry (79). Reports emerging from research studies applying AMPs in ruminants are reviewed elsewhere (193).

Apart from AMPs, milk proteins acts as precursors for many biologically active peptides, including antimicrobial ones. These milk-derived peptides have already been considered for application both as dietary supplements in functional foods and as drugs (202). The number of identified and characterized milk-based bioactive peptides is slowly increasing. Although a number of milk-derived AMPs are now well characterized, key information regarding their structural and functional attributes is still unavailable to potential users. Theolier and coworkers (203) established a milk AMP database that contains valuable information including microbiological and physicochemical data on AMPs of milk protein origin. The database comprised of 371 entries in 2014, including hydrolyzates (9), AMPs (299), peptides predicted as antimicrobial (23), and non-active peptides (40) (203); and has emerged to 944 entries in 2017, as recently reviewed by Nielsen et al. (204). This information would facilitate the study of the potential of these peptides to thwart antibiotic resistance in pathogenic bacteria. Mandal et al. (205) observed the antimicrobial, antioxidant, and growth-stimulating activity of 24 fractions of peptides purified from human milk. Among them, two peptides (f8 and f12) identified as lactoferrinderived peptide and kappa casein short-chain peptide displayed broad-spectrum antimicrobial activities. In a different study, 
mass spectrometry based analysis of the human milk peptidome identified almost 700 endogenous peptides from 30 different proteins, resulting from remarkably specific and well-conserved endogenous proteolytic activity of mammary glands (206).

With the discovery of naturally occurring and synthetic AMPs, attention is being extended to assess antibacterial activity of their structural modifications. Amino acid substitution is one among the simplest approach for enhancing biological activity, as well as reducing cytotoxicity of AMPs (207). In one such study, Lee and coworkers (207), designed a helix-PXXP-helix (HPA3P2) structure, wherein glutamine and phenylalanine replaced proline of HPA3 at 9th and 12th position, respectively. The structural modification dramatically increased the antibacterial activity under in vivo conditions. The modified peptide was also tested for antimicrobial efficacy against MDR $P$. aeruginosa in mice model. Administration of HPA3P2 at a dose of $0.5 \mathrm{mg} / \mathrm{kg}$ body weight ensured $100 \%$ survival rate against MDR P. aeruginosa infection. The improved antimicrobial activity is likely due to the altered mechanism of action of HPA3P. Instead of forming pores in the bacterial plasma membrane, HPA3P permeates the phospholipid bilayer and binds to intracellular RNA and DNA. Also, HPA3P2 acts on the LPS layer of outer cellular membrane of Gram-negative bacteria (207). Collectively, these findings indicate that the modification of peptides can enhance their antibacterial activity manifold and can be explored as an effective therapy against MDR strains. Peptide engineering has fueled the discovery of short and potent AMP derivatives, several of which are currently evaluated under clinical trials (208).

Milk is known to harbor inherited antimicrobial activity, owing to natural milk components and active factors (209). Colostrum, having high natural immunoglobulins concentration outlines the initial acquired immunity for the new born in ruminants. These immunoglobulins are secreted in mammary secretions. Milk, therefore, plays an important role in ruminants host defense (195). Besides immunoglobulins, milk contain viable cells, including macrophages and neutrophils, which further regulates secretion of an array of immune-related components, viz., antimicrobial proteins and peptides, such as, lactoferrin, defensins and cathelicidins, and cytokines. into milk (210). In an interesting study, a modified peptide, L10 (WFRKQLKW), obtained from bovine lactoferrin by selective homologous substitution of amino acids, displayed potent antibacterial and antifungal activity against ESBL producing Gram-negative bacteria and Candida isolates (211). Therefore, milk peptide fractions can serve as therapeutic remedial solution against ESBL producers and MDR fungal strains.

Although AMPs possess potent bactericidal effects and are easily metabolized without adversely effecting the feed quality, few constraints, viz., high production cost; safety concerns (many natural AMPs, viz., melittin, buthotoxin are toxic to eukaryotic cells); chances of resistance development; poor stability during transportation; easy hydrolysis by proteases in the alimentary canal; and pharmacodynamics, pharmacokinetics, and stability claims supported with only a handful of in vivo studies, limit their application as antimicrobial therapy; therefore, a lot of efforts and focus are still needed to categorized them as an effective replacement for antibiotics (79).

\section{PHAGE THERAPY}

Bacteriophages due to their inherent bacterial infection and lysis potential have sought attention of researchers as an antibacterial agent having medical and veterinary application. Phage therapy targets a narrow group of bacteria and prevents dysbiosis normally associated with antibiotic therapy. The autochthonous bacterial flora remains unharmed during phage therapy $(212,213)$. Phages are obligatory parasites and mainly display two types of life cycle, i.e., lytic and lysogenic (214). In lytic phase, following infection, phage lyses the bacterial cell resulting in cell death. However, during lysogeny, phage DNA gets integrated into the bacterial genome. Lytic phages have attracted attention as potent antimicrobials. The mode of action of lysogenic phages includes adsorption to specific bacterial receptors, followed by DNA injection, redirection of host metabolism, DNA replication, and phage protein synthesis. Later, assembly, packing, and release of phage progeny through cell lysis takes place (215). Bacteriophages have the potential to serve as an alternative to antibiotics in the management of animal disease (216). Lytic bacteriophages are safe and target specific, and can be explored as a potential therapeutic agent against bacterial infections (Figure 4) (217).

Most of the research involving bacteriophage as antimicrobial is mainly foccused on the treatment of enteric and respiratory infections in livestock and poultry $(98,218)$. It has been observed that intra-muscular inoculation of phages delayed the appearance of E. coli in the blood, and enhanced the life span of newly borne calves. Various studies reported that administration of phages either orally or topically in animal models, such as mice, guinea pigs, and livestock are quite effective against different pathogens. Coliphages have been employed for successful management of toxigenic E. coli and Salmonella spp. infections. Lytic bacteriophages have also been explored for preventing E. coli-mediated septicemia and meningitis infection in calves (216). In a recent study, Hamza and coworkers (217) described the potential of lytic SA phage against mastitis-causing S. aureus. Recently, Sankar (219) also reported that phage therapy could produce beneficial effect against E. coli- and S. aureus-induced mastitis infection. Earlier, Kwiatek et al. (220) isolated and characterized a bacteriophage having broad-spectrum activity against MRSA isolated from the milk of cows suffering from mastitis. Several earlier reports support the application of phage therapy against bovine mastitis pathogens $(221,222)$.

Foods of bovine origin had been implicated for possible transmission of E. coli O157:H7 to humans (223). Phage mediated in vivo studies have been carried out to control the colonization of E. coli O157:H7 in cattles (224). Rozema et al. (225) evaluated the efficacy of E. coli O157-specific bacteriophages in experimentally inoculated cattle and proposed that regular phage therapy is required to effectively control E. coli O157:H7 shedding in feedlot cattle. Later, Rivas et al. (226) screened e11/2 and e4/1c bacteriophages against E. coli O157:H7 in cattle and observed that when these two phages were challenged individually against E. coli $\mathrm{O} 157: \mathrm{H} 7$ in an ex vivo rumen model, cell numbers were significantly reduced. These phages also showed strong potential 
in reducing E. coli O157:H7 on cattle hide (227). Johnson et al. (228) reported preventive effects of phages over multiple pathogens, viz., Campylobacter spp., E. coli O157:H7, and Salmonella spp. In 2006, a phage cocktail of six types of pure bacteriophages, designated as LMP-102 ${ }^{\mathrm{TM}}$ was approved by US-FDA for application as food additives for preventing Listeria spp. contamination of meat. Later, another phage product was approved by USDA in 2007 for disinfection of E. coli in hidden parts of cattle (79). Phages can also be employed for treatment of viral, fungal, and algal infections in animals (229). The success of phage therapy is limited due to narrow bacterial host range (strict host strain specificity) and due to the requirement of multiple phages for controlling multiple bacterial pathogens. The efficient application of phage therapy requires knowledge about the infectious agent. It is most efficacious when the target pathogen is readily accessible and is present in large numbers (148).

One way to tackle phage associated drawbacks can be the application of purified phage gene products, such as lysins. Endolysins (amidase, endopeptidase, glucosidase and transglycosylase), popularly known as enzybiotics, are mureolytic enzymes generated during the late phage lytic cycle. They target peptidoglycan linkage and lyse bacteria from within, facilitating the release of new phages. Endolysins can quickly kill the susceptible strains and has a wider antibacterial spectrum over phages. Besides, they can also lyse bacteria upon exogenous application (229). Initially, endolysins were shown to be effective in preventing and eliminating bacterial infection by Schuch and coworkers (230). Endolysins isolated from phage $\varphi 3626$ were also shown to treat Clostridium spp. infections (231). Endolysins are specific, highly active, and carries less probability of developing resistance (232). The available literature supports the high possibility of use of phage endolysins for control and treatment of pathogens and infectious disease in dairy animals. However, their antimicrobial application is not yet fully supported with clinical studies. Another bacteriphage mediated strategy can be the application of bacteriophage virion-associated peptidoglycan hydrolases (VAPGHs), those hydrolyzes bacterial peptidoglycan and assists phage entry into the host cell (233). Protein HydH5, a peptidoglycan hydrolase from phage phiIPLA 88 showed antagonistic activity against $S$. aureus (234). The antimicrobial spectrum of VAPGHs from Gram-negative bacterial phages is wider over Gram-positive bacterial phages. They are also effective against some antibiotic-resistant pathogens as well, as they exhibit thermal stability, retaining activity at high temperatures (235). Although there are limited studies in context of purified VAPGHs but instance of bacterial resistance has not been reported so far (233). Hence, VAPGHs can prove to be an effective strategy against pathogens exhibiting MDR.

Bacteriophage application in animals is associated with few shortcomings. The biological consequences of phage therapy need to be considered. It is important to avoid temperate phages for therapeutic application, as there is a possibility of transfer of virulence or antibiotic resistance traits from the phage to the host bacterium. Moreover, obligate lytic phages also carry genes of unknown function that could also lead to undesired gene transfer. Other issues related with phage therapy are the lack of clinical trials data, regulatory loopholes, safety $(236,237)$, stability $(215,236)$, and difficult to obtain intellectual property rights. Therefore, pharmaceutical companies are little reluctant to invest in phage-based products (238). Consequently, most of the bacteriophage products are still in their research phase (79).

\section{CRISPR-Cas}

Genetic strategies targeting temperate bacteriophage as DNA delivery vehicles, has been proposed to abrogate resistance through enhancing the bacterial sensitivity to antibiotics and selectively killing the resistant strains. Recently, Yosef and coworkers (239) reviewed the possible strategies. Sensitizing genes against target antibiotics are identified and incorporated into bacterial genome through lysogenic properties of temperate phages (Figure 4). Prophages thus generated codes for dominant sensitive genes conferring sensitivity to respective antibiotic(s). The sensitivity genes are also linked to tellurite resistance gene, allowing selection of tellurite-resistant and antibiotic-sensitive strains. Thus, this approach helps in selecting the antibiotic-sensitive strains, eliminating the resistant one. However, this approach suffers from several pitfalls, including the selection of strains sensitive to only selective antibiotics, dependence on prior sensitivity to tellurite, narrow host range of temperate phages, and inability to prevent horizontal gene transfer. In a follow up study, the same group targeted temperate phages to deliver CRISPR-Cas (clustered regularly interspaced short palindromic repeats-Cas) system into host bacteria. The CRISPR-Cas was designed to cleave plasmids carrying antibiotic resistance genes, besides conferring protection to specific lytic phages. This approach linked antibiotic sensitivity to phage protection, therefore, selecting only sensitive strains (240). CRISPR-Cas systems employ CRISPR RNAs to recognize and destroy complementary nucleic acids. These are adaptive immune systems native to bacteria and archaea and can be used for sequence-specific killing of target bacterial strains (241). It works on a selective site and creates a double stranded nick in the DNA, modifying or permanently replacing the target sequence (242). Few other studies have reported the successful application of CRISPR-Cas in managing antibiotic resistance and reversing the selection pressure $(243,244)$. The CRISPR-Cas system has also been validated in cell culture for its ability to selectively cleave and destroy hepatitis B virus DNA (245). Recently, TATA firm, India in association with Tel Aviv University, Israel has been quoted to have developed a novel technology that restores bacterial sensitivity to antibiotics, reverse their resistance phenotype, alongwith minimizing virulence. The propsed strategy exploits trojan horse strategy, wherein the natural enemies of bacteria are used to inject foreign DNA into bacetrial cell, which results in an attack mechanism killing target bacterium. In contrary, the DNA may help the cells overcome another stress that selectively targets resistant strains. The DNA carries CRISPR, a DNA-editing technology offer that cuts away the antibiotic-resistant genes. Recent developments in CRISPR-Cas genome editing technology and its potential application in food bacteria has been recently reviewed elsewhere $(242,246)$. CRISPR-Cas technology can have potential application in controlling AMR at dairy farms, through application of developed product, spray, or liquid, etc., in dairy farm envirnonment, dairy personnel hands, etc. However, before 
the technology can be operational and valued as an alternate to antibiotics, in vivo and clinical trials are warranted to standardize it against wide spectra of antibiotic genes, host bacteria, and respective lytic phages (239).

\section{IMMUNOSTIMULANTS}

Immunostimulants are the substance that stimulates the immune system by activation of any of its components and enhances the host's immunity and resistance toward disease in a non-specific manner. They directly enhance innate immune responses through the activation of phagocytes, neutrophils, alternative complement system, and increased lysozyme activity $(247,248)$. Immunostimulants modulate the immune response against pathogen attack through release of cytokines and cytokine inhibitors; limiting end-organ damage via non-specific antiinflammatory agents (e.g., steroids); and transforming a specific antigen-based response through interferons. In addition, some bacterial substances ( $\beta$-glucans) and different plant constituents could directly initiate innate defense mechanisms through expression of intracellular gene(s) controlling production of antimicrobial compounds. Presently, the use of immunostimulants as an alternative to the antibiotics is grooming rapidly. Immunostimulants includes wide array of substances, i.e., mineral substances (selenium, zinc); amino acids (arginine, leucine, ubenimex); vitamins (A, E, C); herbals (Astragalus, Echinacea); plant polysaccharides (algal polysaccharides, Astragalus polysaccharide, chitosan, ganoderan, lentinan, Polyporus polysaccharide); microbial preparations (BCG vaccine, cholera toxin B subunit, Corynebacterium seedlings, muroetasin, Mycobacterium phlei, prodigiosin); bacterial extracts ( $\beta$-glucan, peptidoglycan, lipopolysaccharide); immunologic adjuvants (aluminum adjuvant, propolis, liposome, Freund's adjuvant); hormones and hormone-like substances (growth hormone, metallothionein, thymopentin, thymosin); nucleic acid preparations; chemical synthetics (cimetidine, imiquimod, levomisole, pidotimod, polyinosinic acid, sodium houttuyfonate, tilorone, ubenimex); and biological cytokines (interferon, transfer factor, interleukin, immune globulin) $(79,248,249)$.

Earlier, Bricknell and Dalmo (250) suggested that the application of immunostimulants as animal feed additives could improve their innate defense and provide resistance against pathogen attack during high-stress periods. Gertsch et al. (251) quoted that the application of plant-based immunostimulants as potential therapeutics is undiscovered and stated that the product acts as a tonic for boosting the immune system without actually specifying its mechanisms. In an interesting study, Li et al. (252) examined the effects of chitosan administration in beef cattle and observed improved immune response and antioxidative function. More interestingly, an immune-stimulant, CpG oligo deoxynucleotides induces a systemic innate immune response for small period that occurs after exposure and it also stimulate B-cell proliferation and expression, production of cytokines, and increased NK cell cytotoxicity (253). Bayers launched Zelnate ${ }^{\circledR}$, an innovative cytosine-phosphate-guanine (CpG) motif-based immunostimulant for animal health. It effectively reduces bovine respiratory disease caused by Mannheimia haemolytica. Further research is warranted to describe the specific dosage and efficacy of various immunostimulants. Immunostimulats can be explored to modulate the immune responses which further can act as an adjunct to the antibiotic therapy.

\section{CYTOKINES}

Cytokines, the intercellular regulatory proteins provide cells with the ability to communicate with one another and orchestrate complex multicellular behavior. They are playing an essential role in normal homeostatic tissue functions but up- or downregulation of their networks are associated with pathological conditions. Thus, cytokines themselves could be considered as indicators of inflammation and a useful parameter in diagnosis of infections (254). Cytokines plays an important role in initiating, maintaining, and regulating the innate immune response and are promising candidates for therapeutic interference in infectious and autoimmune diseases (255). Toll-like receptors (TLRs) also plays an important important role in secretion of cytokines. TLRs are evolutionary conserved surface receptors that recognize structural motifs, viz., pathogen associated microbial patterns including lipopolysaccharide, peptidoglycan, flagellin, nucleic acid, etc., of microbial cells. TLRs are predominantly expressed in tissues exposed to external environment and those involved in immue function. Stimulation of TLRs initiates a signaling cascade involving multiple proteins and transcription factors inducing secretion of cytokines directing the adaptive immune response (256). The concentration of cytokines, e.g., TNF- $\alpha$, IL-6, INF- $\gamma$, etc., are usually high in blood serum, milk, uterine washing of cows suffering with subclinical endometritis, mastitis, and other infections and, hence, are proving useful in the diagnosis of these infectious diseases (257).

Cytokines have also been proposed as a therapeutic for bovine mastitis treatment. Application of cytokines alone or as conjunct therapy to antibiotics improves the cure rate of bovine mastitis (258). Recombinant bovine cytokines have also been explored to control and treat bovine mastitis through evoking the host natural defense system. In a study using recombinant cytokines, mammay glands were infused with cytokines (IL-1, IL-2) that led to increased polymorphonuclear cells, with enhanced inducible oxygen radical formation in the milk and thereby effectively preventing $S$. aureus infection (259). The above study indicated that recombinant bovine cytokines can be used to prevent infections in dairy animals; however, more advanced studies are required to be done to accept cytokines as a potential therapeutic and alternative to antibiotics.

\section{QUORUM QUENCHERS (QQ) OR QUORUM SENSING INHIBITORS (QSI)}

Quorum sensing assists bacteria in communication and coordination within themselves and surrounding environment and has been proposed as one of the bacterial mechanism contributing to its pathogenicity (260). Microbial pathogenic behavior is mainly governed through the QS system, comprising of auto-inducers, receptors, and down-stream regulatory proteins, and any pause 
in the system via application of QQ and/or QSI could restrict them $(261,262)$. Three approaches, viz., destruction of autoinducer through enzymatic cleavage or degradation; disruption of auto-inducer synthesis, and inhibition of ligand/receptor interactions are employed to suppress bacterial QS (Figure 4) $(263,264)$. QSIs have been classified into peptide (autoinducing peptide homologs), protein QSIs, and non-peptide small molecules. Non-peptide QSIs includes AHLs analogs, L/D-S-adenosyl homocysteine and butyryl-S-adenosyl-L-methionine; which can interfere with QS signal molecule synthesis or their binding to the receptors (79).

Several veterinary pathogens employ QS for optimizing virulence gene expression and colonization in host. Therefore, any strategy targeting the QS phenomenon among pathogens may help in combating bacterial infections in veterinary medicine, besides addressing resistance. Previously, this strategy has been explored in aquaculture against fish pathogens. Application of AHL analogs reduced the pathogen virulence and associated fish mortality rates (265). Different plants, algae, and fungi have a capability to produce molecules that can inhibit the bacterial QS $(266,267)$.

Importance of QSIs is reflected from extensive research and increasing number of patents in this field in past few years $(268,269)$. QSIs appear to be promising under in vitro studies; however, all the structural classes of compounds researched and patented have faced some challenges under in vivo conditions (270). Although few of the QSI molecules have been tested in preclinical animal models, there clinical application is still un-verified. The QSI, FS3 was screened in a rat model, where it showed good efficacy and synergy with daptomycin (271). Any such agent that disrupts bacterial communication and associated pathogenicity may circumvent the majority of the known resistance mechanisms (270). Direct report of application of QQ and QSIs against MDR strains could not be traced. More concerted efforts are required toward understanding the mechanism and possibilities of large-scale application of QQ or QSIs against infectious and MDR strains.

\section{FEED ENZYMES}

Different enzymes are added to animal feed with the target of assisting the digestion and nutrient bioavailability by acting on feed components within the animal's GIT. There are little chances of enzymatic pre-digestion of the feed substrate during storage (272). Common enzymes used as feed are enlisted in Table 3. These enzymes act as a stimulating factor for the general health and immunity of the livestock which is an important element for reducing the practices of drugs abuse in this field. According to Ravindran and Son (273), a mixture of glycanases and phytase are the most commonly used feed enzymes. For monogastric animals, a range of recombinant synthesized enzymes are commercially available in the form of feed additives (274). However, the advantage of feed enzymes in the form of optimized digestion and enhanced nutrient availability of high-fiber cereal grains and forage is also observed in ruminant livestock (275). Moreover, enzyme like phytase has been reported to have some characteristics effects on mineral
TABLE 3 | Enzymes explored in animal feed [modified from Ref. (272)].

\begin{tabular}{|c|c|c|}
\hline Trivial name & Classification & General function \\
\hline$\alpha$-Amylase & Carbohydrase & Hydrolyzes starch \\
\hline$\beta$-Amylase & & Hydrolyzes starch with production of maltose \\
\hline Cellulase & & Breaks down cellulose \\
\hline$\alpha$-Galactosidase & & Hydrolyzes oligosaccharides \\
\hline$\beta$-Glucanase & & Hydrolyzes $\beta$-glucans \\
\hline$\beta$-Glucosidase & & $\begin{array}{l}\text { Hydrolyzes cellulose with production of } \\
\text { glucose }\end{array}$ \\
\hline Hemicellulase & & Breaks down hemicellulose \\
\hline Invertase & & Hydrolyzes sucrose to glucose and fructose \\
\hline Lactase & & Hydrolyzes lactose to glucose and galactose \\
\hline$\beta$-Mannanase & & Hydrolyzes $\beta$-mannans \\
\hline Pectinase & & Breaks down pectin \\
\hline Pullulanase & & Hydrolyzes starch \\
\hline Xylanase & & Hydrolyzes xylans \\
\hline Lipase & Lipase & $\begin{array}{l}\text { Hydrolyze tri-glycerides, di-glycerides, and } \\
\text { glycerol monoesters }\end{array}$ \\
\hline $\begin{array}{l}\text { Bromelain } \\
\text { Ficain } \\
\text { Papain } \\
\text { Pepsin } \\
\text { Protease } \\
\text { Trypsin }\end{array}$ & Protease & Hydrolyzes proteins \\
\hline $\begin{array}{l}\text { Catalase } \\
\text { Glucose }\end{array}$ & Oxidoreductase & $\begin{array}{l}\text { Produces } \mathrm{H}_{2} \mathrm{O} \text { and } \mathrm{O}_{2} \text { from } \mathrm{H}_{2} \mathrm{O}_{2} \\
\text { Degrades glucose to } \mathrm{H}_{2} \mathrm{O}_{2} \text { and gluconic acid }\end{array}$ \\
\hline Phytase & Phosphatase & Hydrolyzes phytate \\
\hline
\end{tabular}

(i.e., calcium, phosphorus) digestibility along with the production and secretion of mucin, which influence the organization of intestinal epithelial surface and eventually microbial composition of the gut (276). In addition, these exogenous enzymes could impact on microbial population by providing selective nutritional components to specific group of microbes (277). The direct impact of feed enzymes on innate immunity of animal has also been observed. In a study by Tewoldebrhan and coworkers (278) feeding of $\beta$-mannanase enzyme (commercially available as CTCZYME), could reduce the somatic cell counts in milk samples of cows. In light of these findings, it could be deciphered that feed enzymes could be an important factor in controlling the AMR in dairy cattles.

\section{NANOPARTICLES (NPS)}

Over the last few decades, nanotechnology has evolved as a significant branch of science with wider applications, including those in food, veterinary, and animal sciences, particularly against AMR $(279,280)$. NPs can be explored as vehicles for delivery of antimicrobial agents (Figure 4). Several reports proposed the potential application of NPs against bovine mastitis and as an alternative to antimicrobial agents against bacteria and fungi $(281,282)$. Antimicrobial actions of NPs may be through their attachment to the bacterial membrane by electrostatic interaction that may disrupt the integrity of bacterial membrane, alterations in cell wall, blockage of vital enzyme pathways, etc. NPs and their ions induce oxidative stress mediated through generation of reactive oxygen species, which could irreversibly damage bacteria cellular components resulting in death $(283,284)$. 
Antimicrobial activity of nitric oxide and tilmicosin-solid lipid NPs too have been documented against S. aureus spp. (285). Dehkordi et al. (286) documented the antagonistic activity of silver NPs (AgNPs) against $S$. aureus isolated from subclinical mastitis. Xuefeng et al. (287) reported inhibitory activity of amoxicillin NPs against E. coli, S. aureus, and $S$. agalactiae. Berni et al. (288) tested violacein (a powerful anti bactericidal agent) NPs against bovine mastitis and observed high activity of its NPs against $S$. aureus, in comparison to its free form. Kazemi et al. (289) explored synergistic activity of silver NPs (AgNPs) and antibiotics. Co-administration of NPs along with antibiotic inhibited protein translation in $S$. aureus strains. In an interesting study, Kar et al. (290) studied the antibacterial property of AgNPs and capsaicin against MDR and ESBL producing E. coli of bovine and poultry origin and postulated that AgNPs and capsaicin could effectively be used to inhibit the growth of MDR-ESBL producing E. coli. Alizadeh et al. (291) studied the positive antimicrobial effect of AgNPs against $B$. abortus.

ZnO (Zinc oxide) NPs possess antibacterial, antineoplastic, angiogenic, and wound-healing properties, and has been proposed as a feed additive for mastitis management (279). El-Diasty and coworkers (292) evaluated antifungal potential of ZnO NPs on the growth of dermatophytes and proposed its use as an active ingredient for dermatological applications, whereas Atef et al. (293) studied the potential of iron oxide NPs against the bacterial and fungal skin cattle pathogens. Efficacy of different NPs varies with the type of nanomaterial and its size. Although NPs have shown promise in targeting MDR strains, more detailed understanding of their mechanism of action, associated safety concerns, and the environmental and social implications is warranted.

\section{Chicken Egg Yolk Antibodies (IgY)}

$\mathrm{IgY}$ is a major serum immunoglobulin in birds and is available in high concentration from chicken egg yolk. IgY generated by chickens against specific antigens have relatively higher affinity and avidity to antigens and possess high antimicrobial activity (294). These antibodies, besides being safe, economical, specific, and more effective to antibiotics can be targeted against viral or bacterial pathogens, including those having MDR traits (Figure 4). Specific IgY antibodies have been developed against several viral and bacterial pathogens (98). Oral administration of IgY is being currently explored as an alternate strategy to control infectious diseases of gut. Role of IgY in prophylaxis and treatment of rotavirus diarrhea in animal neonates has been recently reviewed in Thu et al. (294). IgY administration has been reported to show promising results in management of several infectious diseases of skin, oral cavity, stomach, intestine, and others. However, being proteinaceous in nature, IgY antibodies are sensitive to GIT stress and may be encapsulated while administering to mammalian gut (294). Recently, avian IgY has also been documented to render protection against dengue (295) and bursal disease virus (296). Available data from in vivo and clinical trials clearly points out their possibility to act as an alternate to current day antibiotics. Additionally, IgY antibodies have several merits over current day antibiotics, as reviewed previously by Rahman et al. (297).

\section{OTHER RECENT DEVELOPMENTS}

In an interesting study, a small molecule was reported to restore the anmicrobial sensitivity of bacterial strains. Upon co-administration with fluoroquinolones, the small molecule IITR08027 reduced its MIC values against MDR A. baumannii. The enhanced sensitivity toward fluoroquinolones was linked to the inhibition of proton gradient and multidrug efflux pump, AbeM. IITR08027 at a concentration of $25 \mu \mathrm{M}$ decreased the MIC values of several antibiotics to significant levels, extended the post-antibiotic effect, and minimized resistant mutant selection (298). Such new strategies hold promise in minimizing and reversing the phenomenon of multidrug resistance, besides increasing the life of antibiotic.

In a recent update in the field of nanotechnology is the bioseperation of bacteria using bacterial targeted NPs. An interesting study by Lu et al. (299) has presented the use of zinc (II)-bis (dipicoly-lamine) modified NPs for delivering a variety of materials to specific Gram-positive and Gram-negative bacterial population. Authors have effectively produced imageable and magnetically active bacterial constructs using optical dyes or iron oxide colloids containing nanoparticls. Subsequently, labled bacteria were efficiently saperated from the solution with the help of a magnetic column. We could speculate the expension of this technique for in situ medical imaging, identification and removal of pathogens, and improved targeted drug dilevery at infection sites in near future.

Against a background of fast emerging resistance to conventional antibiotics, efforts to identify and establish natural alternatives are accelerating and gaining importance. The preceding part attempted to address and propose novel alternative treatment options to current day antibiotics for the welfare of dairy animals. Although a new ray of hope arises with alternative strategies but there is still a huge void between the activity spectrum of antibiotic alternatives and antibiotics itself and regarding their efficacy in disease prevention, growth promotion, and stability. Therefore, intensive efforts from academia, researchers, veterinary doctors, governing bodies, and NGOs are required to propose the control measures through alternative treatments through in vitro and in vivo experiments, which could take the pressure from current day antibiotics and preserve their efficacy. Overall, from existing updates, alternative strategies are displaying promising and encouraging outcomes. However, it is too early to pronounce that they will entirely replace the current day antibiotics and it is proposed that it will be healthier approach if we will explore them as complementary strategy not as replacement policy.

\section{CONCLUSION}

Antimicrobial resistance has been identified as a priority research area and mitigation strategies at different fronts are being planned and explored further; however, its impact and spectra is widening at a much faster pace. Alternate strategies suggested herein may not 
be yet so impactive to completely replace antibiotics as treatment agents, but can be successfully implemented as preventive and management therapy. Along with it, prudent use of antibiotics is quite obligatory to ensure long-term sustainable development of animal husbandry. At the same time, there is need to strengthen the supervision and strict enforcement of laws along with policies pertaining to their usage. Furthermore, there is need to focus on the improvement of animal nutrition and production hygiene. Overall, the dual strategy, i.e., combination of suggested alternative measures along with modest use of antibiotics have promise to pave way for tapping AMR. Moreover, a global, multidisciplinary, long-term approach toward novel diagnostic development and identifying the critical control points is required. Control of AMR should be taken as a "global priority" before it becomes too grim.

\section{REFERENCES}

1. Thakur N, Rokana N, Panwar H. Probiotics: selection criteria, safety and role in health and disease. J Inno Biol (2016) 3(1):259-70.

2. Adrio JL, Demain AL. Microbial enzymes: tools for biotechnological processes. Biomolecules (2014) 4(1):117-39. doi:10.3390/biom4010117

3. Kumar A. Role of microbes in food and industrial microbiology. J Food Ind Microbiol (2016) 2:e101. doi:10.4172/2572-4134.1000e101

4. Tamang JP, Shin D, Jung S, Chia S. Functional properties of microorganisms in fermented foods. Front Microbiol (2016) 7:578. doi:10.3389/ fmicb.2016.00578

5. Abraham EP, Chain E. An enzyme from bacteria able to destroy penicillin. Rev Infect Dis (1940) 10:677-8.

6. World Health Organization. WHO's First Global Report on Antibiotic Resistance Reveals Serious, Worldwide Threat to Public Health. (2014). Available from: http://www.who.int/mediacentre/news/releases/2014/amr-report/en/

7. Ganguly NK, Arora NK, Chandy SJ, Fairoze MN, Gill JP, Gupta U, et al. Rationalizing antibiotic use to limit antibiotic resistance in India. Indian J Med Res (2011) 134(3):281-94.

8. Littmann J, Viens AM. The ethical significance of antimicrobial resistance. Public Health Ethics (2015) 8(3):209-24. doi:10.1093/phe/phv025

9. Hawkey PM, Jones AM. The changing epidemiology of resistance. J Antimicrob Chemother (2009) 64:3-10. doi:10.1093/jac/dkp256

10. Woolhouse M, Ward M, vanBunnik B, Farrar J. Antimicrobial resistance in humans, livestock and the wider environment. Philos Trans R Soc Lond B Biol Sci (2015) 370:20140083. doi:10.1098/rstb.2014.0083

11. Brown K, Uwiera RRE, Kalmokoff ML, Brooks SPJ, Inglis GD. Antimicrobial growth promoter use in livestock: a requirement to understand their modes of action to develop effective alternatives. Int J Antimicrob Agents (2016) 49:12-24. doi:10.1016/j.ijantimicag.2016.08.006

12. Moudgil P, Bedi JS, Moudgil AD, Gill JPS, Aulakh RS. Emerging issue of antibiotic resistance from food producing animals in India: perspective and legal framework. Food Rev Int (2017). doi:10.1080/87559129.2017.1326934

13. Raghunath D. Emerging antibiotic resistance in bacteria with special reference to India. J Biosci (2008) 33(4):593-603. doi:10.1007/s12038-008-0077-9

14. Fridkin SK, Cleveland AA, See I, Lynfield R. Emerging infections program as surveillance for antimicrobial drug resistance. Emerg Infect Dis (2015) 21(9):1578-81. doi:10.3201/eid2109.150512

15. Krehbiel C. The role of new technologies in global food security: improving animal production efficiency and minimizing impacts. Anim Front (2013) 3(3):4-7. doi:10.2527/af.2013-0017

16. Hao H, Cheng G, Iqbal Z, Ai X, Hussain HI, Huang L, et al. Benefits and risks of antimicrobial use in food-producing animals. Front Microbiol (2014) 5:288. doi:10.3389/fmicb.2014.00288

17. Food and Drug Administration. CVM Updates - CVM Reports on Antimicrobials Sold or Distributed for Food-Producing Animals. Maryland: Food Drug Admin, Silver Spring (2010). Available from: https://www.fda. gov/downloads/ForIndustry/UserFees/AnimalDrugUserFeeActADUFA/ UCM277657.pdf

\section{AUTHOR CONTRIBUTIONS}

HP proposed the idea of the review. CS, NR, BS, RG and HP wrote the review draft; JG, PR, and AP helped in improvising the manuscript; NR and CS designed the figures; CS, MC, and HP revised and wrote the final version of the review. The final text has been read and approved by all the authors of the review.

\section{FUNDING}

CS and NR acknowledge the fellowship from SERB-MoFPI (SERB/MoFPI/026/2015), Government of India and BS acknowledge the fellowship from SERB-DST (SB/YS/ LS-131/2014), Government of India.

18. Lhermie G, Grohn YT, Raboisson D. Addressing antimicrobial resistance: an overview of priority actions to prevent suboptimal antimicrobial use in foodanimal production. Front Microbiol (2016) 7:2114. doi:10.3389/fmicb.2016.02114

19. Van Boeckel TP, Brower C, Gilbert M, Grenfell BT, Levin SA, Robinson TP et al. Global trends in antimicrobial use in food animals. Proc Natl Acad Sci U S A (2015) 112(18):5649-54. doi:10.1073/pnas.1503141112

20. Maron DF, Smith TJ, Nachman KE. Restrictions on antimicrobial use in food animal production: an international regulatory and economic survey. Global Health (2013) 9:48. doi:10.1186/1744-8603-9-48

21. Kakkar M, Rogawski L. Antibiotic Use and Residues in Chicken Meat and Milk Samples from Karnataka and Punjab, India: Research Scheme 34. New Delhi: Public Health Found (2013).

22. Basnyat B. Antibiotic resistance needs global solutions. Lancet Infect Dis (2014) 14(7):549-50. doi:10.1016/S1473-3099(14)70800-X

23. Brower CH, Mandal S, Hayer S, Sran M, Zehra A, Patel S, et al. The prevalence of extended-spectrum beta-lactamase-producing multidrug-resistant Escherichia coli in poultry chickens and variation according to farming practices in Punjab, India. Environ Health Perspect (2017) 125(7):077015. doi:10.1289/EHP292

24. Diaz F. Antimicrobial Use in Animals: Analysis of the OIE Survey on Monitoring of the Quantities of Antimicrobial Agents Used in Animals. Paris (2013). Available from: http://www.oie.int/eng/A_AMR2013/Presentations/S2_4_ FrançoisDiaz.pdf

25. McManus MC. Mechanisms of bacterial resistance to antimicrobial agents. Am J Health Syst Pharm (1997) 54(12):1420-33.

26. Martinez JL, Baquero F. Mutation frequencies and antibiotic resistance. Antimicrob Agents Chemother (2000) 44(7):1771-7. doi:10.1128/AAC.44. 7.1771-1777.2000

27. Palmer KL, Kos VN, Gilmore MS. Horizontal gene transfer and the genomics of enterococcal antibiotic resistance. Curr Opin Microbiol (2010) 13(5):632-9. doi:10.1016/j.mib.2010.08.004

28. Jeters RT, Wang GR, Moon K, Shoemaker NB, Salyers AA. Tetracyclineassociated transcriptional regulation of transfer genes of the Bacteroides conjugative transposon CTnDOT. J Bacteriol (2009) 191(20):6374-82. doi:10.1128/JB.00739-09

29. Bailey JK, Pinyon JL, Anantham S, Hall RM. Distribution of the blaTEM gene and blaTEM-containing transposons in commensal Escherichia coli. J Antimicrob Chemother (2011) 66:745-51. doi:10.1093/jac/dkq529

30. Leavis HL, Willems RJ, Top J, Spalburg E, Mascini EM, Fluit AC, et al. Epidemic and nonepidemic multidrug-resistant Enterococcus faecium. Emerg Infect Dis (2003) 9:1108-15. doi:10.3201/eid0909.020383

31. Ramos S, Igrejas G, Rodrigues J, Capelo-Martinez JL, Poeta P. Genetic characterisation of antibiotic resistance and virulence factors in vanA-containing enterococci from cattle, sheep and pigs subsequent to the discontinuation of the use of avoparcin. Vet J (2012) 193:301-3. doi:10.1016/j.tvjl.2011.12.007

32. Cain AK, Liu X, Djordjevic SP, Hall RM. Transposons related to Tn1696 in IncHI2 plasmids in multiply antibiotic resistant Salmonella enterica serovar Typhimurium from Australian animals. Microb Drug Resist (2010) 16:197-202. doi:10.1089/mdr.2010.0042 
33. Cain AK, Hall RM. Evolution of a multiple antibiotic resistance region in IncHI1 plasmids: reshaping resistance regions in situ. J Antimicrob Chemother (2012) 67:2848-53. doi:10.1093/jac/dks317

34. Normanno G, Corrente M, La Salandra G, Dambrosio A, Quaglia NC, Parisi A, et al. Methicillin-resistant Staphylococcus aureus (MRSA) in foods of animal origin product in Italy. Int J Food Microbiol (2007) 117(2):219-22. doi:10.1016/j.ijfoodmicro.2007.04.006

35. Normanno G, La Salandra G, Dambrosio A, Quaglia NC, Corrente M, Parisi A, et al. Occurrence, characterization and antimicrobial resistance of enterotoxigenic Staphylococcus aureus isolated from meat and dairy products. Int J Food Microbiol (2007) 115(3):290-6. doi:10.1016/j.ijfoodmicro. 2006.10.049

36. Sasidharan S, Prema B, Latha LY. Antimicrobial drug resistance of Staphylococcus aureus in dairy products. Asian Pac J Trop Biomed (2011) 1(2):130-2. doi:10.1016/S2221-1691(11)60010-5

37. Jamali H, Paydar M, Radmehr B, Ismail S, Dadrasnia A. Prevalence and antimicrobial resistance of Staphylococcus aureus isolated from raw milk and dairy products. Food Control (2015) 54:383-8. doi:10.1016/j.foodcont.2015. 02.013

38. Harakeh S, Saleh I, Zouhairi O, Baydoun E, Barbour E, Alwan N. Antimicrobial resistance of Listeria monocytogenes isolated from dairybased food products. Sci Total Environ (2009) 407(13):4022-7. doi:10.1016/j. scitotenv.2009.04.010

39. Rahimi E, Ameri M, Momtaz H. Prevalence and antimicrobial resistance of Listeria species isolated from milk and dairy products in Iran. Food Control (2010) 21(11):1448-52. doi:10.1016/j.foodcont.2010.03.014

40. Sawant AA, Hegde NV, Straley BA, Donaldson SC, Love BC, Knabel SJ, et al. Antimicrobial-resistant enteric bacteria from dairy cattle. Appl Environ Microbiol (2007) 3(1):156-63. doi:10.1128/AEM.01551-0

41. Khan A, Das SC, Ramamurthy T, Sikdar A, Khanam J, Yamasaki S, et al. Antibiotic resistance, virulence gene, and molecular profiles of Shiga toxin-producing Escherichia coli isolates from diverse sources in Calcutta, India. J Clin Microbiol(2002) 40(6):2009-15. doi:10.1128/JCM.40.6.2009-2015.2002

42. Ewers C, Bethe A, Semmler T, Guenther S, Wieler LH. Extended spectrum $\beta$ lactamase producing and AmpC producing Escherichia coli from livestock and companion animals, and their putative impact on public health: a global perspective. Clin Microbiol Infect (2012) 18(7):646-55. doi:10.1111/j. 1469-0691.2012.03850

43. Carattoli A. Animal reservoirs for extended spectrum $\beta$ lactamase producers. Clin Microbiol Infect (2008) 14(s1):117-23. doi:10.1111/j.1469-0691. 2007.01851.x

44. Addis Z, Kebede N, Sisay Z, Alemayehu H, Wubetie A, Kassa T. Prevalence and antimicrobial resistance of Salmonella isolated from lactating cows and in contact humans in dairy farms of Addis Ababa: a cross sectional study. BMC Infect Dis (2011) 11(1):222. doi:10.1186/1471-2334-11-222

45. Marshall BM, Levy SB. Food animals and antimicrobials: impacts on human health. Clin Microbiol Rev (2011) 24:718-33. doi:10.1128/CMR.00002-11

46. Chang Q, Wang W, Regev-Yochay G, Lipsitch M, Hanage WP. Antibiotics in agriculture and the risk to human health: how worried should we be? Evol Appl (2015) 8:240-5. doi:10.1111/eva.12185

47. Coetzee J, Corcoran C, Prentice E, Moodley M, Mendelson M, Poirel L, et al. Emergence of plasmid-mediated colistin resistance (MCR-1) among Escherichia coli isolated from South African patients. S Afr Med J (2016) 106:449-50. doi:10.7196/samj.2016.v106i5.10710

48. Liu YY, Wang Y, Walsh TR, Yi LX, Zhang R, Spencer J, et al. Emergence of plasmid-mediated colistin resistance mechanism MCR-1 in animals and human beings in China: a microbiological and molecular biological study. Lancet Infect Dis (2016) 16(2):161-8. doi:10.1016/S1473-3099(15)00424-7

49. Founou LL, Founou RC, Essack SY. Antibiotic resistance in the food chain: a developing country-perspective. Front Microbiol (2016) 7:1881. doi:10.3389/ fmicb.2016.01881

50. Horigana V, Kosmider RD, Horton RA, Randall L, Simons RRL. An assessment of evidence data gaps in the investigation of possible transmission routes of extended spectrum-lactamase producing Escherichia coli from livestock to humans in the UK. Prev Vet Med (2016) 124:1-8. doi:10.1016/j. prevetmed.2015.12.020

51. Kock R, Kreienbrock L, Van Duijkeren E, Schwarz S. Antimicrobial resistance at the interface of human and veterinary medicine. Vet Microbiol (2016) 200:1-5. doi:10.1016/j.vetmic.2016.11.013
52. Chantziaras I, Boyen F, Callens B, Dewulf J. Correlation between veterinary antimicrobial use and antimicrobial resistance in food-producing animals: a report on seven countries. J Antimicrob Chemother (2014) 69:827-34. doi:10.1093/jac/dkt443

53. OIE, World Organisation for Animal Health. Aquatic Animal Health Code. 15th ed. Paris: OIE (2012). Available from: www.oie.int/en/internationalstandard-setting/aquatic-code/

54. OIE, World Organisation for Animal Health. Terrestrial Animal Health Code. 21st ed. Paris: OIE (2012). Available from: http://www.oie.int/ international-standard-setting/terrestrial-code/

55. Codex Alimentarius Commission. Guidelines for Risk Analysis of Foodborne Antimicrobial Resistance. CAC/GL 77. Rome: Codex Alimentarius Commission (2011). Available from: www.fao.org/input/download/standards/11776/CXG_077e.pdf

56. Silley P, Simjee S, Schwarz S. Surveillance and monitoring of antimicrobial resistance and antibiotic consumption in humans and animals. Rev Sci Tech (2012) 31(1):105-20. doi:10.20506/rst.31.1.2100

57. Acar JF, Moulin G. Integrating animal health surveillance and food safety: the issue of antimicrobial resistance. Rev Sci Tech (2013) 32(2):383-92. doi: $10.20506 /$ rst.32.2.2230

58. Danish Integrated Antimicrobial Resistance Monitoring and Research Programme. Use of Antimicrobial Agents and Occurrence of Antimicrobial Resistance in Bacteria from Food Animals, Foods and Humans in Denmark. (2005). Available from: https://www.danmap.org/ /media/Projekt\%20sites/ Danmap/DANMAP\%20reports/Danmap_2005.ashx

59. Tollefson L. FDA reveals plans for antimicrobial susceptibility monitoring $J$ Am Vet Med Assoc (1996) 208:459-60.

60. McEwen SA, Fedorka-Cray PJ. Antimicrobial use and resistance in animals. Clin Infect Dis (2002) 34:S93-106. doi:10.1086/340246

61. European Medicines Agency. Trends in the Sales of Veterinary Antimicrobial Agents in Nine European Countries (2005-2009) (EMA/238630/2011). London: European Medicines Agency (2011). Available from: http:// www.ema.europa.eu/docs/en_GB/document_library/Report/2011/09/ WC500112309.pdf

62. de Jong A, Thomas V, Klein U, Marion H, Moyaert H, Simjee S, et al. Pan-European resistance monitoring programmes encompassing foodborne bacteria and target pathogens of food-producing and companion animals. Int J Antimicrob Agents (2013) 41:403-9. doi:10.1016/j.ijantimicag. 2012.11.004

63. Martel J, Coudert M. Bacterial resistance monitoring in animals: the French national experiences of surveillance schemes. Vet Microbiol (1993) 35:321-38. doi:10.1016/0378-1135(93)90157-3

64. Moreno MA, Domínguez L, Teshager T, Herrero IA, Porrero MC, de Ávila LDSA, et al. Antibiotic resistance monitoring: the Spanish programme. Int J Antimicrob Agents (2000) 14(4):285-90. doi:10.1016/S09248579(00)00138-2

65. Porrero MC, Garcia M, Teshager T, Cubillo I, Rivero E, Rigaut D, et al. Veterinary Monitoring of Antimicrobial Resistance in Spain, VAV 2005, 12th Report, Ed. 1. Madrid: CERSA (2006). Available from: www.vigilanciasanitaria.es/en/veterinary-monitoring-ofantimicrobial-resistance-inspain-vav-2005-twelfthreport $/ 12=320 /$

66. Public Health Agency of Canada. Canadian Integrated Program for Antimicrobial Resistance Surveillance (CIPARS). Ottawa, ON: Public Health Agency of Canada (2006). Available from: www.phac-aspc.gc.ca/ciparspicra/index-eng.php

67. Yamamoto T, Hayama Y, Hidano A, Kobayashi S, Muroga N, Ishikawa K, et al. Sampling strategies in antimicrobial resistance monitoring: evaluating how precision and sensitivity vary with the number of animals sampled per farm. PLoS One (2014) 9(1):e87147. doi:10.1371/journal. pone.0087147

68. Ministry of Health and Family Welfare. National Policy for Containment of Antimicrobial Resistance, India. (2011). Available from: http://www.ncdc.gov. in/ab_policy.pdf

69. World Health Organization. Prevention and containment of antimicrobial resistance. Report of a Regional Meeting Chiang Mai, Thailand, $8^{\text {th }}$ to $11^{\text {th }}$ of June 2010. (2010). Available from: http://www.searo.who.int/entity/ antimicrobial_resistance/BCT_Reports_SEA-HLM-408.pdf?ua=1

70. Behera B, Mathur P. High levels of antimicrobial resistance at a tertiary trauma care centre of India. Indian J Med Res (2011) 133(3):343-5. 
71. Lascols C, Hackel M, Marshall SH, Hujer AM, Bouchillon S, Badal R, et al. Increasing prevalence and dissemination of NDM-1 metallo-betalactamase in India: data from the SMART study (2009). JAntimicrob Chemother (2009) 66:1992-7. doi:10.1093/jac/dkr240

72. Borah VV, Saikia KK, Chandra P, Hazarika NK, Chakravarty R. New Delhi metallo-beta-lactamase and extended spectrum beta-lactamases co-producing isolates are high in community-acquired urinary infections in Assam as detected by a novel multiplex polymerase chain reaction assay. Indian J Med Microbiol (2016) 34:173-82. doi:10.4103/0255-0857. 176853

73. Tanwar J, Das S, Fatima Z, Hameed S. Multidrug resistance: an emerging crisis. Interdiscip Perspect Infect Dis (2014) 7:541340. doi:10.1155/ 2014/541340

74. Food and Agriculture Organization of the United Nations. The FAO Action Plan on Antimicrobial Resistance 2016-2020. Rome: Food and Agriculture Organization of the United Nations (2016).

75. World Health Organization. Global Action Plan on Antimicrobial Resistance. Geneva: World Health Organization (2015).

76. Laxminarayan R, Duse A, Wattal C, Zaidi AK, Wertheim HF, Sumpradit N, et al. Antibiotic resistance - the need for global solutions. Lancet Infect Dis (2013) 13(12):1057-98. doi:10.1016/S1473-3099(13)70318-9

77. DiMasi JA. Innovation in the Pharmaceutical Industry: New Estimates of R\&D Costs, Tufts Center for the Study of Drug Development. (2014). Available from: http://csdd.tufts.edu/files/uploads/Tufts_CSDD_briefing_on_RD_cost_ study_-_Nov_18,_2014..pdf

78. Elder DP, Kuentz M, Holm R. Antibiotic resistance: the need for a global strategy. J Pharm Sci (2016) 105(8):2278-87. doi:10.1016/j.xphs.2016.06.002

79. Cheng G, Hao H, Xie S, Wang X, Dai M, Huang L, et al. Antibiotic alternatives: the substitution of antibiotics in animal husbandry. Front Microbiol (2014) 5:69-83. doi:10.3389/fmicb.2014.00217

80. Mishra RPN, Oviedo-Orta E, Prachi P, Rappuoli R, Bagnoli F. Vaccines and antibiotic resistance. Curr Opin Microbiol (2012) 15(5):596-602. doi:10.1016/j.mib.2012.08.002

81. Merino O, Alberdi P, de la Lastra JMP, de la Fuente J. Tick vaccines and the control of tick-borne pathogens. Front Cell Infect Microbiol (2013) 3:30. doi:10.3389/fcimb. 2013.00030

82. Stary G, Olive A, Radovic-Moreno AF, Gondek D, Alvarez D, Basto PA, et al. A mucosal vaccine against Chlamydia trachomatis generates two waves of protective memory T cells. Science (2015) 348(6241):8205. doi:10.1126/ science.aaa8205

83. Wang S, Zeng X, Yang Q, Qiao S. Antimicrobial peptides as potential alternatives to antibiotics in food animal industry. Int J Mol Sci (2016) 17(5):603. doi:10.3390/ijms17050603

84. McVey S, Shi J. Vaccines in veterinary medicine: a brief review of history and technology. Vet Clin North Am Small Anim Pract (2010) 40:381-92. doi:10.1016/j.cvsm.2010.02.001

85. Dellagostin OA, Felix SR, Jorge S. Recombinant veterinary vaccines. In: Soccol VT, Pandey A, Resende R, editors. Current Developments in Biotechnology and Bioengineering, Human and Animal Health Applications. (2017). p. 439-58. doi:10.1016/B978-0-444-63660-7.00017-6

86. Riosa AC, Moutinhob CG, Pinto FC, Del Fiola FS, Jozalaa A, Chauda MV, et al. Alternatives to overcoming bacterial resistances: state-of-the-art. Microbiol Res (2016) 191:51-80. doi:10.1016/j.micres.2016.04.008

87. Jensen TH, Nielsen L, Aasted B, Pertoldi C, Blixenkrone-Møller M. Canine distemper virus DNA vaccination of mink can overcome interference by maternal antibodies. Vaccine (2015) 33(11):1375-81. doi:10.1016/j. vaccine.2015.01.029

88. Liu X, Liu Q, Xiao K, Li P, Liu Q, Zhao X, et al. Attenuated Salmonella Typhimurium delivery of a novel DNA vaccine induces immune responses and provides protection against duck enteritis virus. Vet Microbiol (2016) 186:189-98. doi:10.1016/j.vetmic.2016.03.001

89. Shakya M, Kumar B, Nagar G, Fuente J, Ghosh S. Subolesis: a candidate vaccine antigen for the control of cattle tick infestations in Indian situation. Vaccine (2014) 32(28):3488-94. doi:10.1016/j.vaccine.2014.04.053

90. Mcallister MM. Successful vaccines for naturally occurring protozoal diseases of animals should guide human vaccine research. A review of protozoal vaccines and their designs. Parasitology (2014) 141(5):624-40. doi:10.1017/S0031182013002060
91. Rizzi C, Bianco MV, Blanco FC, Soria M, Gravisaco MJ, Montenegro V, et al. Vaccination with a BCG strain overexpressing Ag85B protects cattle against Mycobacterium bovis challenge. PLoS One (2012) 7(12):e51396. doi:10.1371/ journal.pone.0051396

92. Potter A, Gerdts V, Littel-van den Hurk SV. Veterinary vaccines: alternatives to antibiotics? Anim Health Res Rev (2008) 9(2):187-99. doi:10.1017/ S1466252308001606

93. Tiwari J, Babra C, Tiwari HK, Williams V, De Wet S, Gibson J, et al. Trends in therapeutic and prevention strategies for management of bovine mastitis: an overview. J Vaccines Vaccin (2013) 4(2):1000176. doi:10.4172/ 2157-7560.1000176

94. Sayed ML, Shell WS, Hanan AA, Hanan MI, Nasr EA, Ali AM. Efficacy of a locally prepared bovine mastitis vaccine. Benha Vet Med J (2015) 29(2):309-18.

95. Michon C, Langella P, Eijsink VGH, Mathiesen G, Chatel JM. Display of recombinant proteins at the surface of lactic acid bacteria: strategies and applications. Microb Cell Fact (2016) 15:70. doi:10.1186/s12934016-0468-9

96. Kumar R, Sreenivasa BP, Tamilselvan RP. Construction and characterization of recombinant human adenovirus type 5 expressing foot-and-mouth disease virus capsid proteins of Indian vaccine strain, O/IND/R2/75. Vet World (2015) 8(2):147-55. doi:10.14202/vetworld.2015.147-155

97. Kumar M, Sarvanan P, Jalali SK. Expression and purification of virus like particles (VLPs) of foot and mouth disease virus in Eri silkworm (Samia Cynthia ricini) larve. Virus Dis (2016) 27(1):84-90. doi:10.1007/s13337015-0290-8

98. Tiwari R, Chakraborty S, Dhama K, Rajagunalan S, Singh SV. Antibiotic resistance - an emerging health problem: causes, worries, challenges and solutions - a review. Int J Curr Res (2013) 5(07):1880-92.

99. Poulet H, Minke J, Pardo MC, Juillard V, Nordgren B, Audonnet JC. Development and registration of recombinant veterinary vaccines: the example of the canarypox vector platform. Vaccine (2007) 25(30):5606-12. doi:10.1016/j.vaccine.2006.11.066

100. Kalayou S, Haileselassie M, Gebre-egziabher G, Tiku’e T, Sahle S, Taddele H, et al. In-vitro antimicrobial activity screening of some ethnoveterinary medicinal plants traditionally used against mastitis, wound and gastrointestinal tract complication in Tigray Region, Ethiopia. Asian Pac J Trop Biomed (2012) 2(7):512-22. doi:10.1016/S2221-1691(12)60088-4

101. Narayana VL, Rao GMN. Ethnoveterinary practices and phytochemical analysis of some selected medicinal plants from north coastal Andhra Pradesh, India. Indian J Appl Res (2015) 5(9):455-7.

102. Dhama K, Tiwari R, Chakraborty S, Saminathan M, Kumar A, Karthik K, et al. Evidence based antibacterial potentials of medicinal plants and herbs countering bacterial pathogens especially in the era of emerging drug resistance: an integrated update. Int J pharmacol (2014) 10(1):1-43. doi:10.3923/ ijp.2014.1.43

103. Hashemi SR, Davoodi H. Herbalplantsandtheirderivativesas growth and health promoters in animal nutrition. Vet Res Commun (2011) 35:169-80. doi:10.1007/s11259-010-9458-2

104. Abreu AC, McBain AJ, Simoes M. Plants as sources of new antimicrobials and resistance-modifying agents. Nat Prod Rep (2012) 29:1007-21. doi:10.1039/c2np20035j

105. Savoia D. Plant-derived antimicrobial compounds: alternatives to antibiotics. Future Microbiol (2012) 7(8):979-90. doi:10.2217/fmb.12.68

106. Atanasov AG, Waltenberger B, Pferschy-Wenzig EM, Linder T, Wawrosch C, Uhrin P, et al. Discovery and resupply of pharmacologically active plantderived natural products: a review. Biotechnol Adv (2015) 33:1582-614. doi:10.1016/j.biotechadv.2015.08.001

107. Taga I, Lan CQ, Altosaar I. Plant essential oils and mastitis disease: their potential inhibitory effects on pro-inflammatory cytokine production in response to bacteria related inflammation. Nat Prod Commun (2012) $7(5): 675-82$.

108. Ghosh S, Banerjee S, Sil PC. The beneficial role of curcumin on inflammation, diabetes and neurodegenerative disease: a recent update. Food Chem Toxicol (2015) 83:111-24. doi:10.1016/j.fct.2015.05.022

109. Brooks VJ, Peek SF, Godbee RG, Schultz RD, Suresh M, Darien BJ. Effects of Morinda citrifolia (Noni) on CD4+ and CD8+ T-cell activation in neonatal calves. Prof Anim Sci (2009) 25:262-5. 
110. Yancey JWS, Apple JK, Kegley EB, Goodbee RG. Effects of Morinda citrifolia (Noni) pulp on growth performance and stress responses of growing cattle. Prof Anim Sci (2013) 29(4):420-5. doi:10.15232/S1080-7446(15)30255-2

111. Ghosh S, Mehla RK, Sirohi SK, Roy B. The effect of dietary garlic supplementation on body weight gain, feed intake, feed conversion efficiency, faecal score, faecal coliform count and feeding cost in crossbred dairy calves. Trop Anim Health Prod (2010) 42(5):961-8. doi:10.1007/ s11250-009-9514-5

112. Ghosh S, Mehla RK, Sirohi SK, Tomar SK. Performance of crossbred calves with dietary supplementation of garlic extract. J Anim Physiol Anim Nutr (2011) 95(4):449-55. doi:10.1111/j.1439-0396.2010.01071.x

113. Luseba D, Tshisikhawe MP. Medicinal plants used in the treatment of livestock diseases in Vhembe region, Limpopo province, South Africa. J Med Plants Res (2013) 7(10):593-601. doi:10.5897/JMPR012.1213

114. Panda SS, Dhal NK. Plants used in ethno-veterinary medicine by native people of Nawarangpur district, Odisha, India. World J Pharm Pharm Sci (2014) 3(7):787-98.

115. Andrade FI, Purgato GA, Maia TF, Siqueira RP, Lima S, Diaz G, et al. Chemical constituents and an alternative medicinal veterinary herbal soap made from Senna macranthera. Evid Based Complement Alternat Med (2015) 2015:217598. doi:10.1155/2015/217598

116. Kinde H, Regassa F, Asaye M, Wubie A. The in-vitro antibacterial effect of three selected plant extracts against Staphylococcus aureus and Streptococcus agalactiae isolated from bovine mastitis. J Vet Sci Technol (2015) 6(13):S13. doi:10.4172/2157-7579.1000S13-001

117. Megeed KNA, Hammam AM, Morsy GH, Khalil FAM, Seliem MME, Aboelsoued D. Control of cryptosporidiosis in buffalo calves using garlic (Allium sativum) and nitazoxanide with special reference to some biochemical parameters. Global Vet (2015) 14(5):646-55. doi:10.5829/idosi. gv.2015.14.05.94137

118. Dantas ACS, Machado DMR, Araujo AC, Oliveira-Junior RG, LimaSaraiva SRG, Ribeiro LAA, et al. Acaricidal activity of extracts from the leaves and aerial parts of Neoglaziovia variegata (bromeliaceae) on the cattle tick Rhipicephalus (Boophilus) microplus. Res Vet Sci (2015) 100:165-8. doi:10.1016/j.rvsc.2015.04.012

119. Balkrishna A, Kumar HM, Kumari D, Kumari H, Gupta AK. Isolation, screening of mastitis causing bacteria and antibacterial effect of poly herbal formulation. Int J Rec Sci Res (2016) 7(5):11440-4.

120. Mushtaq S, Rather MA, Qazi PH, Aga MA, Shah AM, Shah A, et al. Isolation and characterization of three benzylisoquinoline alkaloids from Thalictrum minus L. and their antibacterial activity against bovine mastitis. J Ethnopharmacol (2016) 193:221-6. doi:10.1016/j.jep.2016.07.040

121. Zhu H, Du M, Fox L, Zhu MJ. Bactericidal effects of Cinnamon cassia oil against bovine mastitis bacterial pathogens. Food Control (2016) 66:291-9. doi:10.1016/j.foodcont.2016.02.013

122. Singh MVKG, Mondal DB, Shakya M, Sharma DK. Evaluation of antbacterial and therapeutic potential of Holarrhena antidysenterica bark extract in calf diarrhea. Int J Adv Res (2016) 4(8):1334-9. doi:10.21474/IJAR01/1334

123. Amber R, Adnan M, Tariq A, Khan SN, Mussarat S, Hashem A, et al. Antibacterial activity of selected medicinal plants of northwest Pakistan traditionally used against mastitis in livestock. Saudi J Biol Sci (2017). doi:10.1016/j.sjbs.2017.02.008

124. Medina MFE, Alaba PA, Estrada-Zuniga ME, Velazquez-Ordonez V, Barbabosa-Pliego A, Salem MZ, et al. Anti-staphylococcal properties of four plant extracts against sensitive and multiresistant bacterial strains isolated from cattle and rabbits. Microb Pathog (2017) 113:286-94. doi:10.1016/j. micpath.2017.10.053

125. Sserunkuma P, McGaw LJ, Nsahlai IV, Van Staden J. Selected southern African medicinal plants with low cytotoxicity and good activity against bovine mastitis pathogens. S Afr J Bot (2017) 111:242-7. doi:10.1016/j. sajb.2017.03.032

126. Mudzengi CP, Murwira A, Tivapasi M, Murungweni C, Burumu JV, Halimani T. Antibacterial activity of aqueous and methanol extracts of selected species used in livestock health management. Pharm Biol (2017) 55(1):1054-60. doi:10.1080/13880209.2017.1287744

127. Punniamurthy N, Ramakrishnan N, Nair MNB, Vijayaraghavan S. In-vitro antimicrobial activity of ethnoveterinary herbal preparation for mastitis. J Dairy Vet Sci (2017) 3(2):1-2. doi:10.19080/JDVS.2017.03.555607
128. Pasca C, Marghitas L, Dezmirean D, Bobis O, Bonta V, Chirila F, et al. Medicinal plants based products tested on pathogens isolated from mastitis milk. Molecules (2017) 22:1473. doi:10.3390/molecules 22091473

129. El-Desoukey RMA. Phytochemical and antimicrobial activity of Panicum turgidum (thummam) as a grazing herb against some animal pathogens. EC Microbiol (2017) 5(1):22-9.

130. Nanon A, Suksombat W, Yang WZ. Effects of essential oils supplementation on in vitro and in situ feed digestion in beef cattle. Anim Feed Sci Technol (2014) 196:50-9. doi:10.1016/j.anifeedsci.2014.07.006

131. Jeshari M, Riasi A, Mahdavi AH, Khorvash M, Ahmadi F. Effect of essential oils and distillation residues blends on growth performance and blood metabolites of Holstein calves weaned gradually or abruptly. Livest Sci (2016) 185:117-22. doi:10.1016/j.livsci.2015.12.011

132. Guil-Guerrero JL, Ramos L, Moreno C, Zúniga-Paredes JC, CarlosamaYépez M, Ruales P. Antimicrobial activity of plant-food by-products: a review focusing on the tropics. Livest Sci (2016) 189:32-49. doi:10.1016/j. livsci.2016.04.021

133. Guil-Guerrero JL, Ramos L, Moreno C, Zúniga-Paredes JC, Carlosama-Yépez M, Ruales P. Plant-food by-products to improve farm-animal health. Anim Feed Sci Technol (2016) 220:121-35. doi:10.1016/j.anifeedsci.2016.07.016

134. Reddy MK, Gupta SK, Jacob MR, Khan SI, Ferreira D. Antioxidant, antimalarial and antimicrobial activities of tannin-rich fractions, ellagitannins and phenolic acids from Punica granatum L. Planta Med (2007) 53:461-7. doi:10.1055/s-2007-967167

135. Miyasaki Y, Nichola WS, Morgan MA, Kwan JA, Van Benschoten MM, Kittel PE, et al. Screening of herbal extracts against multi-drug resistant Acinetobacter baumannii. Phytother Res (2010) 24:1202-6. doi:10.1002/ ptr.3113

136. Kipre BG, Guessennd NK, Kone MW, Gbonon V, Coulibaly JK, Dosso M. Antibacterial activity of the stem bark of Tieghemella heckelii Pierre ex. A Chev against methicillin-resistant Staphylococcus aureus. BMC Complement Altern Med (2017) 17:170. doi:10.1186/s12906-017-1681-8

137. Singh V, Jaryal M, Gupta J, Kumar P. Antibacterial activity of medicinal plants against extended spectrum beta lactamase producing bacteria causing urinary tract infection. Int J Drug Res Technol (2017) 2(3):4.

138. Upadhyaya I, Upadhyay A, Kollanoor-Johny A, Mooyottu S, Baskaran SA, Yin HB, et al. In-feed supplementation of trans-cinnamaldehyde reduces layerchicken egg-borne transmission of Salmonella enterica serovar enteritidis. Appl Environ Microbiol (2015) 81(9):2985-94. doi:10.1128/AEM.03809-14

139. Huyghebaert G, Ducatelle R, VanImmerseel F. An update on alternatives to antimicrobial growth promoters for broilers. Vet J (2011) 187:182-8. doi:10.1016/j.tvjl.2010.03.003

140. Baffoni L, Gaggìa F, di Gioia D, Santini C, Mogna L, Biavati B. A Bifidobacterium-based synbiotic product to reduce the transmission of C. jejuni along the poultry food chain. Int JFood Microbiol (2012) 157(2):156-61. doi:10.1016/j.ijfoodmicro.2012.04.024

141. D’Orazio G, Di Gennaro P, Boccarusso M, Presti I, Bizzaro G, Giardina S, et al. Microencapsulation of new probiotic formulations for gastrointestinal delivery: in vitro study to assess viability and biological properties. Appl Microbiol Biotechnol (2015) 99(22):9779-89. doi:10.1007/s00253-015-6853-1

142. Varankovich NV, Nickerson MT, Korber DR. Probiotic-based strategies for therapeutic and prophylactic use against multiple gastrointestinal diseases. Front Microbiol (2015) 6:685. doi:10.3389/fmicb.2015.00685

143. Imperial IC, Ibana JA. Addressing the antibiotic resistance problem with probiotics: reducing the risk of its double-edged sword effect. Front Microbiol (2016) 7:1983. doi:10.3389/fmicb.2016.01983

144. Tellez G, Laukova A, Latorre JD, Hernandez-Velasco X, Hargis BM, Callaway T. Food-producing animals and their health in relation to human health. Microb Ecol Health Dis (2015) 26:25876. doi:10.3402/mehd.v26.25876

145. Muñoz-Atienza E, Gómez-Sala B, Araújo C, Campanero C, Del Campo R, Hernández PE, et al. Antimicrobial activity, antibiotic susceptibility and virulence factors of lactic acid bacteria of aquatic origin intended for use as probiotics in aquaculture. BMC Microbiol (2013) 13(1):15. doi:10.1186/ 1471-2180-13-15

146. Frizzo LS, Soto LP, Zbrun MV, Signorini ML, Bertozzi E, Sequeira G, et al. Effect of lactic acid bacteria and lactose on growth performance and intestinal microbial balance of artificially reared calves. Livest Sci (2011) 140(1):246-52. doi:10.1016/j.livsci.2011.04.002 
147. Bayatkouhsar J, Tahmasebi AM, Naserian AA, Mokarram RR, Valizadeh R. Effects of supplementation of lactic acid bacteria on growth performance, blood metabolites and fecal coliform and lactobacilli of young dairy calves. Anim Feed Sci Technol (2013) 186:1-11. doi:10.1016/j.anifeedsci. 2013.04.015

148. Allen HK, Levine UY, Looft T, Bandrick M, Casey TA. Treatment, promotion, commotion: antibiotic alternatives in food-producing animals. Trends Microbiol (2013) 21:114-9. doi:10.1016/j.tim.2012.11.001

149. Uyeno Y, Shigemori S, Shimosato T. Effect of probiotics/prebiotics on cattle health and productivity. Microbes Environ (2015) 30(2):126-32. doi:10.1264/ jsme2.ME14176

150. Oyetayo VO, Oyetayo FL. Potential of probiotics as biotherapeutic agents targeting the innate immune system. Afr J Biotechnol (2005) 4(2):123-7.

151. Casas IA, Dobrogosz WJ. Validation of the probiotic concept: Lactobacillus reuteri confers broad-spectrum protection against disease in humans and animals. Microb Ecol Health Dis (2000) 12(4):247-85. doi:10.1080/ 08910600050216246-1

152. Musa HH, We SL, Zhu CH, Seri HI, Zhu GQ. The potential benefits of probiotics in animal production and health. J Anim Vet Adv (2009) 8:313-21.

153. Retta KS. Role of probiotics in rumen fermentation and animal performance: a review. Int J Livest Prod (2016) 7(5):24-32. doi:10.5897/ IJLP2016.0285

154. Jamalifar H, Rahimi HR, Samadi N, Shahverdi AR, Sharifian Z, Hosseini F, et al. Antimicrobial activity of different Lactobacillus species against multidrug resistant clinical isolates of Pseudomonas aeruginosa. Iran J Microbiol (2011) 3(1):21-5.

155. Lee DK, Kim MJ, Kang JY, Park JE, Shin HS, Ha NJ. Probiotics with antimicrobial activity against multidrug resistant Pseudomonas aeruginosa and Acinetobacter baumannii. Korean J Microbiol (2013) 49(3):245-52. doi:10.7845/kjm.2013.3048

156. Mirnejad R, Vahdati AR, Rashidiani J, Erfani M, Piranfar V. The antimicrobial effect of Lactobacillus casei culture supernatant against multiple drug resistant clinical isolates of Shigella sonnei and Shigella flexneri in vitro. Iran Red Crescent Med (2013) 15(2):122-6. doi:10.5812/ircmj.7454

157. Naderi A, Kasra-Kermanshahi R, Gharavi S, Fooladi AAI, Alitappeh MA, Saffarian P. Study of antagonistic effects of Lactobacillus strains as probiotics on multi drug resistant (MDR) bacteria isolated from urinary tract infections (UTIs). Iran J Basic Med Sci (2014) 17(3):201-8.

158. Ripamonti B, Tirloni E, Stella S, Bersani C, Agazzi A, Maroccolo S, et al. Effects of a species-specific probiotic formulation on multiresistant Escherichia coli isolates from the gut of veal calves. Czech J Anim Sci (2013) 5:201-7.

159. Ahasan ASML, Agazzi A, Invernizzi G, Bontempo V, Savoini G. The beneficial role of probiotics in monogastric animal nutrition and health. J Dairy Vet Anim Res (2015) 2(4):00041. doi:10.15406/jdvar.2015.02.00041

160. Yirga H. The use of probiotics in animal nutrition. J Prob Health (2015) 3:132. doi:10.4172/2329-8901.1000132

161. Gulbe G, Valdovska A, Saulite V, Jermolajevs J. In vitro assessment for antimicrobial activity of Lactobacillus helveticus and its natural glycopeptides against mastitis causing pathogens in dairy cattle. Open Biotechnol J (2015) 9:61-6. doi:10.2174/1874070701509010061

162. Ohya T, Akiba M, Ito $\mathrm{H}$. Use of a trial probiotic product in calves experimentally infected with Escherichia coli O157. Japan Agric Res Q (2001) 35:189-94. doi:10.6090/jarq.35.189

163. Rodriguez-Palacios A, Staempfli HR, Duffield T, Weese JS. Isolation of bovine intestinal Lactobacillus plantarum and Pediococcus acidilactici with inhibitory activity against Escherichia coli O157 and F5. J Appl Microbiol (2009) 106(2):393-401. doi:10.1111/j.1365-2672.2008.03959

164. Kim GB, Seo YM, Kim CH, Paik IK. Effect of dietary prebiotic supplementation on the performance, intestinal microflora, and immune response of broilers. Poult Sci (2011) 90(1):75-82. doi:10.3382/ps.2010-00732

165. Nakashimada Y, Michinaka A, Watanabe K, Nishio N, Fujii T. Brewer's yeast cell wall affects microbiota composition and decreases Bacteroides fragilis populations in an anaerobic gut intestinal model. JBiosci Bioeng (2011) 111(2):178-84. doi:10.1016/j.jbiosc.2010.09.005

166. Quigley JD, Kost CJ, Wolfe TA. Effects of spray-dried animal plasma in milk replacers or additives containing serum and oligosaccharides on growth and health of calves. J Dairy Sci (2002) 85(2):413-21. doi:10.3168/jds.S00220302(02)74089-7
167. Benyacoub J, Rochat F, Saudan KY, Rochat I, Antille N, Cherbut C, et al. Feeding a diet containing a fructooligosaccharide mix can enhance Salmonella vaccine efficacy in mice. J Nutr (2008) 138(1):123-9.

168. Baines D, Erb S, Lowe R, Turkington K, Sabau E, Kuldau G, et al. A prebiotic, Celmanax ${ }^{\mathrm{TM}}$, decreases Escherichia coli O157: $\mathrm{H} 7$ colonization of bovine cells and feed-associated cytotoxicity in vitro. BMC Res Notes (2011) 4(1):110. doi:10.1186/1756-0500-4-110

169. Vandeplas S, Dubois Dauphin R, Beckers Y, Thonart P, Thewis A. Salmonella in chicken: current and developing strategies to reduce contamination at farm level. J Food Prot (2010) 73(4):774-85. doi:10.4315/0362-028X73.4.774

170. Hamasalim HJ. Synbiotic as feed additives relating to animal health and performance. Adv Microbiol (2016) 6:288-302. doi:10.4236/aim.2016.64028

171. Bomba A, Nemcova R, Mudronova D, Guba P. The possibilities of potentiating the efficacy of probiotics. Trends Food Sci Technol (2002) 13:121-6. doi:10.1016/S0924-2244(02)00129-2

172. Asahara T, Takahashi A, Yuki N, Kaji R, Takahashi T, Nomoto K. Protective effect of a synbiotic against multidrug-resistant Acinetobacter baumannii in a murine infection model. Antimicrob Agents Chemother (2016) 60:3041-50. doi:10.1128/AAC.02928-15

173. Sharma C, Gulati S, Thakur N, Singh BP, Gupta S, Kaur S, et al. Antibiotic sensitivity pattern of indigenous lactobacilli isolated from curd and human milk samples. 3 Biotech (2017) 7:53. doi:10.1007/s13205-017-0682-0

174. Yang SC, Lin CH, Sung CT, Fang JY. Antibacterial activities of bacteriocins: application in foods and pharmaceuticals. Front Microbiol (2014) 5:241. doi:10.3389/fmicb.2014.00241

175. Umu OC, Bauerl C, Oostindjer M, Pope PB, Hernández PE, Pérez-Martínez G, et al. The potential of class II bacteriocins to modify Gut microbiota to improve host health. PLoS One (2016) 11(10):e0164036. doi:10.1371/journal. pone. 0164036

176. Mohanasirivasan V, Suganthi V, Selvarajan E, Subathradevi C. LantibioticNisin: natural preservative from Lactococcus lactis. Int Res JPhar (2012) 3(1):13-9.

177. Karpiński TM, Szkaradkiewicz AK. Characteristic of bacteriocines and their application. Pol J Microbiol (2013) 62(3):223-35.

178. Bemena LD, Mohamed LA, Fernandes AM, Lee BH. Applications of bacteriocins in food, livestock health and medicine. Int J Curr Microbiol App Sci (2014) 3(12):924-49. doi:10.13140/RG.2.1.3426.2488

179. Tong Z, Zhang Y, Ling J, Ma J, Huang L, Zhang L. In vitro study on the effects of nisin on the antibacterial activities of 18 antibiotics against Enterococcus faecalis. PLoS One (2014) 9:e89209. doi:10.1371/journal. pone.0089209

180. Ceotto-Vigoder H, Marques SL, Santos IN, Alves MD, Barrias ES, Potter A, et al. Nisin and lysostaphin activity against preformed biofilm of Staphylococcus aureus involved in bovine mastitis. J Appl Microbiol (2016) 121: 101-14. doi:10.1111/jam.13136

181. McCaughey LC, Ritchie ND, Douce GR, Evans TJ, Walker D. Efficacy of species-specific protein antibiotics in a murine model of acute Pseudomonas aeruginosa lung infection. Sci Rep (2016) 6:30201. doi:10.1038/ srep30201

182. Pieterse R, Todorov SD, Dicks LMT. Mode of action and in vitro susceptibility of mastitis pathogens to macedocin ST91KM and preparation of a teat seal containing the bacteriocin. Braz J Microbiol (2010) 41:133-45. doi:10.1590/ S1517-838220100001000020

183. Klostermann K, Crispie F, Flynn J, Meaney WJ, Paul RR, Hill C. Efficacy of a teat dip containing the bacteriocinlacticin 3147 to eliminate Gram-positive pathogens associated with bovine mastitis. J Dairy Res (2010) 77:231-8. doi:10.1017/S0022029909990239

184. Rea MC, Sit CS, Clayton E, O'Connor PM, Whittal RM, Zheng J, et al. Thuricin $\mathrm{CD}$, a posttranslationally modified bacteriocin with a narrow spectrum of activity against Clostridium difficile. Proc Natl Acad Sci U S A (2010) 107(20):9352-7. doi:10.1073/pnas.0913554107

185. Wirawan RE, Klesse NA, Jack RW, Tagg JR. Molecular and genetic characterization of a novel nisin variant produced by Streptococcus uberis. Appl Environ Microbiol (2006) 72:1148-56. doi:10.1128/AEM.72.2.11481156.2006

186. Wirawan RE, Swanson KM, Kleffmann T, Jack RW, Tagg JR. Uberolysin: a novel cyclic bacteriocin produced by Streptococcus uberis. Microbiology (2007) 153:1619-30. doi:10.1099/mic.0.2006/005967-0 
187. Wu J, Hu S, Cao L. Therapeutic effect of nisin $\mathrm{Z}$ on subclinical mastitis in lactating cows. Antimicrob Agents Chemother (2007) 51(9):3131-5. doi:10.1128/ AAC.00629-07

188. Barboza-Corona JE, de la Fuente-Salcido N, Alva-Murillo N, Ochoa-Zarzosa A, Lopez-Meza JE. Activity of bacteriocins synthesized by Bacillus thuringiensis against Staphylococcus aureus isolates associated to bovine mastitis. Vet Microbiol (2009) 138:179-83. doi:10.1016/j.vetmic.2009.03.018

189. Salvucci E, Saavedra L, Hebert EM, Haro C, Sesma F. Enterocin CRL35 inhibits Listeria monocytogenes in a murine model. Foodborne Pathog Dis (2012) 9(1):68-74. doi:10.1089/fpd.2011.0972

190. Cursino L, Smajs DS, Marda J, Nardi RMD, Nicoli JR, Chartone-Souza E, et al. Exoproducts of the Escherichia coli strain H22 inhibiting some enteric pathogens both in vitro and in vivo. J Appl Microbiol (2006) 100:821-9. doi:10.1111/j.1365-2672.2006.02834.x

191. Huang E, Zhang L, Chung YK, Zheng Z, Yousef AE. Characterization and application of enterocin RM6, a bacteriocin from Enterococcus faecalis. Biomed Res Int (2013):206917. doi:10.1155/2013/206917

192. Narayana JL, Chen JY. Antimicrobial peptides: possible anti-infective agents. Peptides (2015) 72:88-94. doi:10.1016/j.peptides.2015.05.012

193. Cheema UB, Younas M, Sultan JI, Iqbal A, Tariq M, Waheed A. Antimicrobial peptides: an alternative of antibiotics in ruminants. Adv Agric Biotechnol (2011) 2:15-21.

194. Thacker PA. Alternatives to antibiotics as growth promoters for use in swine production: a review. J Anim Sci Biotechnol (2013) 4:35. doi:10.1186/ 2049-1891-4-35

195. Brogden KA, Ackermann M, McCray PB, Tack BF. Antimicrobial peptides in animals and their role in host defences. Int J Antimicrob Agents (2003) 22(5):465-78. doi:10.1016/S0924-8579(03)00180-8

196. Islas-Rodrìguez AE, Marcellini L, Orioni B, Barra D, Stella L, Mangoni ML. Esculentin 1-21: a linear antimicrobial peptide from frog skin with inhibitory effect on bovine mastitis-causing bacteria. J Pept Sci (2009) 15(9): 607-14. doi:10.1002/psc.1148

197. Metz-Boutigue MH, Goumon Y, Lugardon K, Strub JM, Aunis D. Antibacterial peptides are present in chromaffin cell secretory granules. Cell Mol Neurobiol (1998) 18:249-66. doi:10.1023/A:1022573004910

198. Dashper SG, O’Brien-Simpson NM, Cross KJ, Paolini RA, Hoffmann B, Catmull DV, et al. Divalent metal cations increase the activity of the antimicrobial peptide kappacin. Antimicrob Agents Chemother (2005) 49:2322-8. doi:10.1128/AAC.49.6.2322-2328.2005

199. Dashper S, Liu S, Reynolds E. Antimicrobial peptides and their potential as oral therapeutic agents. Int J Pept Res Ther (2007) 13:505-16. doi:10.1007/ s10989-007-9094-Z

200. Strub JM, Goumon Y, Lugardon K, Capon C, Lopez M, Moniatte M, et al. Antibacterial activity of glycosylated and phosphorylated chromogranin A-derived peptide 173-194 from bovine adrenal medullary chromaffin granules. J Biol Chem (1996) 271(45):28533-40. doi:10.1074/jbc.271.45.28533

201. Zhang JX, Zhang SF, Wang TD, Guo XJ, Hu RL. Mammary gland expression of antibacterial peptide genes to inhibit bacterial pathogens causing mastitis. J Dairy Sci (2007) 90:5218-25. doi:10.3168/jds.2007-0301

202. Akalın AS. Dairy-derived antimicrobial peptides: action mechanisms, pharmaceutical uses and production proposals. Trends Food Sci Technol (2014) 36(2):79-95. doi:10.1016/j.tifs.2014.01.002

203. Theolier J, Fliss I, Jean J, Hammami R. Milk AMP: a comprehensive database of antimicrobial peptides of dairy origin. Dairy Sci Technol (2014) 94(2):181-93. doi:10.1007/s13594-013-0153-2

204. Nielsen SD, Beverly RL, Qu Y, Dallas DC. Milk bioactive peptide database: a comprehensive database of milk protein-derived bioactive peptides and novel visualization. Food Chem (2017) 232:673-82. doi:10.1016/j. foodchem.2017.04.056

205. Mandal SM, Bharti R, Porto WF, Gauri SS, Mandal M, Franco OL, et al. Identification of multifunctional peptides from human milk. Peptides (2014) 56:84-93. doi:10.1016/j.peptides.2014.03.017

206. Guerrero A, Dallas DC, Contreras S, Chee S, Parker EA, Sun X, et al. Mechanistic peptidomics: factors that dictate specificity in the formation of endogenous peptides in human milk. Mol Cell Proteomics (2014) 13:3343-51. doi:10.1074/mcp.M113.036194

207. Lee JK, Park SC, Hahm KS, Park YK. A helix-PXXP-helix peptide with antibacterial activity without cytotoxicity against MDRPA-infected mice. Biomaterials (2014) 35(3):1025-39. doi:10.1016/j.biomaterials.2013.10.035
208. Padhi A, Sengupta M, Sengupta S, Roehm KH, Sonawane A. Antimicrobial peptides and proteins in mycobacterial therapy: current status and future prospects. Tuberculosis (2014) 94(4):363-73. doi:10.1016/j.tube.2014.03.011

209. Panwar H. Biologically active components of human and bovine milk as potent antimicrobial agents. J Innov Biol (2014) 1(2):97-104.

210. Jenssen H, Hancock RE. Antimicrobial properties of lactoferrin. Biochimie (2009) 91(1):19-29. doi:10.1016/j.biochi.2008.05.015

211. Mishra B, Leishangthem GD, Gill K, Singh AK, Das S, Singh K, et al. A novel antimicrobial peptide derived from modified N-terminal domain of bovine lactoferrin: design, synthesis, activity against multidrug-resistant bacteria and Candida. Biochim Biophys Acta1 (2013) 828(2):677-86. doi:10.1016/j.bbamem.2012.09.021

212. Abedon ST, Kuhl SJ, Blasdel BG, Kutter EM. Phage treatment of human infections. Bacteriophage (2011) 1(2):66-85. doi:10.4161/bact.1.2.15845

213. Buttimer C, McAuliffe O, Ross RP, Hill C, O'Mahony J, Coffey A. Bacteriophages and bacterial plant diseases. Front Microbiol (2017) 8:34. doi:10.3389/fmicb.2017.00034

214. Weinbauer MG. Ecology of prokaryotic viruses. FEMS Microbiol Rev (2004) 28(2):127-81. doi:10.1016/j.femsre.2003.08.001

215. Drulis-Kawa Z, Majkowska-Skrobek G, Maciejewska B, Delattre AS, Lavigne R. Learning from bacteriophages-advantages and limitations of phage and phage-encoded protein applications. Curr Protein Pept Sci (2012) 13(8):699-722. doi:10.2174/138920312804871193

216. Tiwari R, Dhama K, Chakraborty S, Kumar A, Rahal A, Kapoor S. Bacteriophage therapy for safeguarding animal and human health: a review. Pak J Biol Sci (2014) 17(3):301-15. doi:10.3923/pjbs.2014.301.315

217. Hamza A, Perveen S, Abbas Z, Ur Rehman S. The lytic SA phage demonstrates bactericidalactivity against mastitis causing Staphylococcus aureus. Open Life Sci (2016) 11:39-45. doi:10.1515/biol-2016-0005

218. Tiwari R, Hirpurkar SD. Therapeutic potential of lytic phages against chronic wound infections. Indian Vet J (2011) 88:1375-7.

219. Sankar P. New therapeutic strategies to control and treatment of bovine mastitis. Vet Med Open J (2016) 1(2):e7-8. doi:10.17140/VMOJ-1-e004

220. Kwiatek M, Parasion S, Mizak L, Gryko R, Bartoszcze M, Kocik J. Characterization of a bacteriophage, isolated from a cow with mastitis, that is lytic against Staphylococcus aureus strains. Arch Virol (2012) 157(2):225-34. doi:10.1007/s00705-011-1160-3

221. Gill JJ, Pacan JC, Carson ME, Leslie KE, Griffiths MW, Sabour PM. Efficacy and pharmacokinetics of bacteriophage therapy in treatment of subclinical Staphylococcus aureus mastitis in lactating dairy cattle. Antimicrob Agents Chemother (2006) 50(9):2912-8. doi:10.1128/AAC.01630-05

222. O’Flaherty S, Ross RP, Meaney W, Fitzgerald GF, Elbreki MF, Coffey A. Potential of the polyvalent anti-Staphylococcus bacteriophage $\mathrm{K}$ for control of antibiotic resistant staphylococci from hospitals. Appl Environ Microb (2005) 71:1836-42. doi:10.1128/AEM.71.4.1836-1842.2005

223. Endersen L, O’Mahony J, Hill C, Ross RP, McAuliffe O, Coffey A. Phage therapy in the food industry. Annu Rev Food Sci Technol (2014) 5:327-49. doi:10.1146/annurev-food-030713-092415

224. Goodridge LD, Bisha B. Phage-based biocontrol strategies to reduce foodborne pathogens in foods. Bacteriophage (2011) 1:30-7. doi:10.4161/bact.1.3.17629

225. Rozema EA, Stephens TP, Bach SJ, Okine EK, Johnson RP, Stanford KIM, et al. Oral and rectal administration of bacteriophages for control of Escherichia coli O157: H7 in feedlot cattle. J Food Prot (2009) 72(2):241-50. doi:10.4315/0362-028X-72.2.241

226. Rivas L, Coffey B, McAuliffe O, McDonnell MJ, Burgess CM, Coffey A, et al. In vivo and ex vivo evaluations of bacteriophages e11/2 and e4/1c for use in the control of Escherichia coli O157: H7. Appl Environ Microbiol (2010) 76(21):7210-6. doi:10.1128/AEM.01530-10

227. Coffey B, Rivas L, Duffy G, Coffey A, Ross RP, McAuliffe O. Assessment of Escherichia coli O157: H7-specific bacteriophages e11/2 and e4/1c in model broth and hide environments. Int J Food Microbiol (2011) 147(3):188-94. doi:10.1016/j.ijfoodmicro.2011.04.001

228. Johnson RP, Gyles CL, Huff WE, Ojha S, Huff GR, Rath NC, et al. Bacteriophages for prophylaxis and therapy in cattle, poultry and pigs. Anim Health Res Rev (2008) 9(2):201-15. doi:10.1017/S1466252308001576

229. Tiwari R, Chakraborty S, Dhama K, Wani MY, Kumar A, Kapoor S. Wonder world of phages: potential biocontrol agents safeguarding biosphere and health of animals and humans - current scenario and perspectives. Pak J Biol Sci (2014) 17:316-28. doi:10.3923/pjbs.2014.316.328 
230. Schuch R, Nelson D, Fischetti VA. A bacteriolytic agent that detects and kills Bacillus anthracis. Nature (2002) 418:884-9. doi:10.1038/nature01026

231. Courchesne NM, Parisien A, Lan CQ. Production and application of bacteriophage and bacteriophage-encoded lysins. Recent Pat Biotechnol (2009) 3(1):37-45. doi:10.2174/187220809787172678

232. Tiwari R, Dhama K, Chakraborty S, Kapoor S. Enzybiotics: new weapon in the army of antimicrobials: a review. Asian J Anim Vet Adv (2014) 9(3):144-63. doi:10.3923/ajava.2014.144.163

233. Rodriguez-Rubio L, Martínez B, Donovan DM, Rodríguez A, García P. Bacteriophage virion-associated peptidoglycan hydrolases: potential new enzybiotics. Crit Rev Microbiol (2013) 39(4):427-34. doi:10.3109/10408 41X.2012.723675

234. Rodríguez L, Martínez B, Zhou Y, Rodríguez A, Donovan DM, García P. Lytic activity of the virion-associated peptidoglycan hydrolase HydH5 of Staphylococcus aureus bacteriophage vB_SauS-phiIPLA88. BMC Microbiol (2011) 11(1):138. doi:10.1186/1471-2180-11-138

235. Rodriguez-Rubio L, Martínez B, Rodríguez A, Donovan DM, García P. Enhanced staphylolytic activity of the Staphylococcus aureus bacteriophage vB_SauS-phiIPLA88 HydH5 virion-associated peptidoglycan hydrolase: fusions, deletions, and synergy with LysH5. Appl Environ Microbiol (2012) 78(7):2241-8. doi:10.1128/AEM.07621-11

236. PirnayJP, De Vos D, Verbeken G, Merabishvili M, ChanishviliN, Vaneechoutte M, et al. The phage therapy paradigm: pret-a-porter or sur-mesure? Pharm Res (2011) 28(4):934-7. doi:10.1007/s11095-010-0313-5

237. Miedzybrodzki R, Borysowski J, Weber-Dabrowska B, Fortuna W, Letkiewicz S, Szufnarowski K, et al. Clinical aspects of phage therapy. Adv Virus Res (2012) 83:73-121. doi:10.1016/B978-0-12-394438-2.00003-7

238. Nobrega FL, Costa AR, Kluskens LD, Azeredo J. Revisiting phage therapy: new applications for old resources. Trends Microbiol (2015) 23(4):185-91. doi:10.1016/j.tim.2015.01.006

239. Yosef I, Manor M, Qimron U. Counteracting selection for antibioticresistant bacteria. Bacteriophage (2016) 6(1):e1096996. doi:10.1080/21597081. 2015.1096996

240. Yosef I, Manor M, Kiro R, Qimron U. Temperate and lytic bacteriophages programmed to sensitize and kill antibiotic-resistant bacteria. Proc Natl Acad Sci U S A (2015) 112:7267-72. doi:10.1073/pnas.1500107112

241. Beisel CL, Gomaa AA, Barrangou R. A CRISPR design for next-generation antimicrobials. Genome Biol (2014) 15:516. doi:10.1186/s13059-0140516-x

242. Singh V, Gohil N, Garcia RR, Braddick D, Fofie CK. Recent advances in CRISPR-Cas9 genome editing technology for biological and biomedical investigations. J Cell Biochem (2017) 119(1):81-94. doi:10.1002/jcb.26165

243. Bikard D, Euler CW, Jiang W, Nussenzweig PM, Goldberg GW, Duportet X, et al. Exploiting CRISPR-Cas nucleases to produce sequence-specific antimicrobials. Nat Biotechnol (2014) 32:1146-50. doi:10.1038/nbt.3043

244. Citorik RJ, Mimee M, Lu TK. Sequence-specific antimicrobials using efficiently delivered RNA guided nucleases. Nat Biotechnol (2014) 32(11):1141-5. doi:10.1038/nbt.3011

245. Kennedy EM, Kornepati AVR, Cullen BR. Targeting hepatitis B virus cccDNA using CRISPR/Cas9. Antiviral Res (2015) 123:188-92. doi:10.1016/j. antiviral.2015.10.004

246. Stout E, Klaenhammer T, Barrangou R. CRISPR-Cas technologies and applications in food bacteria. Annu Rev Food Sci Technol (2017) 8:413-37. doi:10.1146/annurev-food-072816-024723

247. Sakai M. Current research status of fish immunostimulants. Aquacult (1999) 172(1):63-92. doi:10.1016/S0044-8486(98)00436-0

248. Song SK, Beck BR, Kim D, Park J, Kim J, Kim HD, et al. Prebiotics as immunostimulants in aquaculture: a review. Fish Shellfish Immunol (2014) 40(1):40-8. doi:10.1016/j.fsi.2014.06.016

249. Masihi KN. Immunomodulators in infectious diseases: panoply of possibilites. Int J Immunopharmacol (2000) 22(12):1083-91. doi:10.1016/ S0192-0561(00)00074-6

250. Bricknell I, Dalmo RA. The use of immunostimulants in fish larval aquaculture. Fish Shellfish Immunol (2005) 19(5):457-72. doi:10.1016/j. fsi.2005.03.008

251. Gertsch J, Viveros-Paredes JM, Taylor P. Plant immunostimulants - scientific paradigm or myth? JEthnopharmacol (2011) 136(3):385-91. doi:10.1016/j. jep.2010.06.044
252. Li T, Na R, Yu P, Shi B, Yan S, Zhao Y, et al. Effects of dietary supplementation of chitosan on immune and antioxidative function in beef cattle. Czech J Anim Sci (2015) 60:38-44. doi:10.17221/7910-CJAS

253. Thacker EL. Immunomodulators, immunostimulants, and immunotherapies in small animal veterinary medicine. Vet Clin North Am Small Anim Pract (2010) 40(3):473-83. doi:10.1016/j.cvsm.2010.01.004

254. Becher B, Spath S, Goverman J. Cytokine networks in neuroinflammation. Nat Rev Immunol (2017) 17:49-59. doi:10.1038/nri.2016.123

255. Dhama K, Chakraborty S, Wani MY, Tiwari R, Barathidasan R. Cytokine therapy for combating animal and human diseases - a review. Res Opin Anim Vet Sci (2013) 3(7):195-208.

256. Singh BP, Chauhan RS, Singhal LK. Toll-like receptors and their role in innate immunity. Curr Sci (2003) 85(8):1156-64.

257. Brodzki P, Kostro K, Krakowski L, Marczuk J. Inflammatory cytokine and acute phase protein concentrations in the peripheral blood and uterine washings of cows with subclinical endometritis in the late postpartum period. Vet Res Commun (2015) 39(2):143-9. doi:10.1007/ s11259-015-9635-4

258. Hossain MK, Paul S, Hossain MM, Islam MR, Alam MGS. Bovine mastitis and its therapeutic strategy doing antibiotic sensitivity test. Austin J Vet Sci Anim Husb (2017) 4(1):1030.

259. Daley M, Williams T, Coyle P, Furda G, Dougherty R, Hayes P. Prevention and treatment of Staphylococcus aureus infections with recombinant cytokines. Cytokine (1993) 5(3):276-84. doi:10.1016/1043-4666(93) 90015-W

260. Basavaraju M, Sisnity VS, Palaparthy R, Addanki PK. Quorum quenching: signal jamming in dental plaque biofilms. J Dent Sci (2016) 11:349-52. doi:10.1016/j.jds.2016.02.002

261. Tay SB, Yew WS. Development of quorum-based anti-virulence therapeutics targeting Gram-negative bacterial pathogens. Int J Mol Sci (2013) 14(8):16570-99. doi:10.3390/ijms140816570

262. LaSarre B, Federle MJ. Exploiting quorum sensing to confuse bacterial pathogens. Microbiol Mol Biol Rev (2013) 77(1):73-111. doi:10.1128/ MMBR.00046-12

263. Chen F, Gao Y, Chen X, Yu Z, Li X. Quorum quenching enzymes and their application in degrading signal molecules to block quorum sensingdependent infection. Int J Mol Sci (2013) 14(9):17477-500. doi:10.3390/ ijms140917477

264. Hirakawa H, Tomita H. Interference of bacterial cell-to-cell communication: a new concept of antimicrobial chemotherapy breaks antibiotic resistance. Front Microbiol (2013) 4:114. doi:10.3389/fmicb.2013.00114

265. Boyen F, Eeckhaut V, Van Immerseel F, Pasmans F, Ducatelle R, Haesebrouck F. Quorum sensing in veterinary pathogens: mechanisms, clinical importance and future perspectives. Vet Microbiol (2009) 135:187-95. doi:10.1016/j. vetmic.2008.12.025

266. Koh CL, Sam CK, Yin WF, Tan LY, Krishnan T, Chong YM, et al. Plantderived natural products as sources of anti-quorum sensing compounds. Sensors (2013) 13(5):6217-28. doi:10.3390/s130506217

267. Tan LY, Yin WF, Chan KG. Piper nigrum, Piper betle and Gnetum gnemonnatural food sources with anti-quorum sensing properties. Sensors (2013) 13(3):3975-85. doi:10.3390/s130303975

268. Kalia VC, Purohit HJ. Quenching the quorum sensing system: potential antibacterial drug targets. Crit Rev Microbiol (2011) 37(2):121-40. doi:10.3109/ 1040841X.2010.532479

269. Romero M, Acuna L, Otero A. Patents on quorum quenching: interfering with bacterial communication as a strategy to fight infections. Recent Pat Biotechnol (2012) 6:2-12. doi:10.2174/187220812799789208

270. Bhardwaj AK, Vinothkumar K, Rajpara N. Bacterial quorum sensing inhibitors: attractive alternatives for control of infectious pathogens showing multiple drug resistance. Recent Pat Antiinfect Drug Discov (2013) 8(1):68-83. doi:10.2174/157489113805290809

271. Cirioni O, Mocchegiani F, Cacciatore I, Vecchiet J, Silvestri C, Baldassarre L, et al. Quorum sensing inhibitor FS3-coated vascular graft enhances daptomycin efficacy in a rat model of staphylococcal infection. Peptides (2013) 40:77-81. doi:10.1016/j.peptides.2012.12.002

272. Pariza MW, Cook M. Determining the safety of enzymes used in animal feed. Regul Toxicol Pharmacol (2010) 56:332-42. doi:10.1016/j.yrtph.2009. 10.005 
273. Ravindran V, Son JH. Feed enzyme technology: present status and future developments. Recent Pat Food Nutr Agric (2011) 3(2):102-9. doi:10.2174/ 2212798411103020102

274. Adeola O, Cowieson AJ. Board-invited review: opportunities and challenges in using exogenous enzymes to improve nonruminant animal production. J Anim Sci (2011) 89:3189-218. doi:10.2527/jas.2010-3715

275. Colombatto D, Morgavi DP, Furtado AF, Beauchemin KA. Screening of exogenous enzymes for ruminant diets: relationship between biochemical characteristics and in vitro ruminal degradation. J Anim Sci (2003) 81(10):2628-38. doi:10.2527/2003.81102628x

276. Knowlton KF, Taylor MS, Hill SR, Cobb C, Wilson KF. Manure nutrient excretion by lactating cows fed exogenous phytase and cellulase. J Dairy Sci (2007) 90(9):4356-60. doi:10.3168/jds.2006-879

277. Bedford MR, Cowieson AJ. Exogenous enzymes and their effects on intestinal microbiology. Anim Feed Sci Technol (2012) 173:76-85. doi:10.1016/j. anifeedsci.2011.12.018

278. Tewoldebrhan TA, Appuhamy JADRN, Lee JJ, Niu M, Seo S, Jeong S, et al. Exogenous $\beta$-mannanase improves feed conversion efficiency and reduces somatic cell count in dairy cattle. J Dairy Sci (2017) 100(1):244-52. doi:10.3168/jds.2016-11017

279. Raguvaran R, Manuja A, Manuja BK. Zinc oxide nanoparticles: opportunities and challenges in veterinary sciences. Immunome Res (2015) 11:2. doi:10.4172/1745-7580.1000095

280. Sharma C, Dhiman R, Rokana N, Panwar H. Nanotechnology: an untapped resource for food packaging. Front Micrbiol (2017) 8:1735. doi:10.3389/ fmicb.2017.01735

281. Seil JT, Webster TJ. Antimicrobial applications of nanotechnology: methods and literature. Int J Nanomedicine (2012) 7:2767-81. doi:10.2147/IJN. S24805

282. Gomes F, Henriques M. Control of bovine mastitis: old and recent therapeutic approaches. Curr Microbiol (2016) 72:377-82. doi:10.1007/ s00284-015-0958-8

283. Hajipour MJ, Fromm KM, Ashkarran AA, de Aberasturi DJ, de Larramendi IR, Rojo T, et al. Antibacterial properties of nanoparticles. Trends Biotechnol (2012) 30(10):499-511. doi:10.1016/j.tibtech.2012.06.004

284. Yah CS, Simate GS. Nanoparticles as potential new generation broad spectrum antimicrobial agents. DARU J Pharm Sci (2015) 23:43. doi:10.1186/ s40199-015-0125-6

285. Cardozo VF, Lancheros CA, Narciso AM, Valereto EC, Kobayashi RK, Seabra AB, et al. Evaluation of antibacterial activity of nitric oxide-releasing polymeric particles against Staphylococcus aureus and Escherichia coli from bovine mastitis. Int J Pharm (2014) 473(1-2):20-9. doi:10.1016/j. ijpharm.2014.06.051

286. Dehkordi SH, Hosseinpour F, Kahrizangi AE. An in vitro evaluation of antibacterial effect of silver nanoparticles on Staphylococcus aureus isolated from bovine subclinical mastitis. Afr J Biotechnol (2011) 10(52):10795-7. doi:10.5897/AJB11.1499

287. Xuefeng Y, Wuqing O, Jiangcai S, XiangHui L. Post-antibiotic effect of amoxicillin nanoparticles against main pathogenic bacteria of bovine mastitis in vitro. J Northwest AF Univ (2009) 37(6):1-6.

288. Berni E, Marcato PD, Nakazato G, Kobayashi RKT, Vacchi FI, Umbuzeiro GA, et al. Violacein/poly (e-caprolactone)/chitosan nanoparticles against bovine mastistis: antibacterial and ecotoxicity evaluation. J Phys Conf Ser (2013) 429(1):2030. doi:10.1088/1742-6596/429/1/012030
289. Kazemi J, Malahat A, Habib D, Saei M, Adib H. Antibacterial effect of silver nanoparticles along with protein synthesis-inhibiting antibiotics on Staphylococcus aureus isolated from cattle mastitis. Biol J Micro (2014) 8:15-22.

290. Kar D, Bandyopadhyay S, Dimri U, Mondal DB, Nanda PK, Das AK, et al. Antibacterial effect of silver nanoparticles and capsaicin against MDRESBL producing Escherichia coli: an in vitro study. Asian Pac J Trop Dis (2016) 6(10):807-10. doi:10.1016/S2222-1808(16)61135-0

291. Alizadeh H, Salouti M, Shapouri R. Bactericidal effect of silver nanoparticles on intramacrophage Brucella abortus 544. Jundishapur J Microbiol (2014) 7(3):e9039. doi:10.5812/jjm.9039

292. El-Diasty EM, Ahmed MA, Okasha N, Mansour SF, El-Dek S, El-Khalek HM, et al. Antifungal activity of zinc oxide nanoparticles against dermatophytic lesions of cattle. Rom J Biophys (2013) 23(3):191-202.

293. Atef HA, Oraby NH, El-Dahshan EME, Ali MA. Antimicrobial potential of iron oxide nanoparticles in control of some causes of microbial skin affection in cattle. Eur J Acad Essays (2015) 2(6):20-31.

294. Thu HM, Myat TW, Win MM, Thant KZ, Rahman S, Umeda K, et al. Chicken egg yolk antibodies (IgY) for prophylaxis and treatment of rotavirus diarrhea in human and animal neonates: a concise review. Korean J Food Sci Anim Resour (2017) 37(1):1-9. doi:10.5851/kosfa.2017.37.1.1

295. Fink AL, Williams KL, Harris E, Alvine TD, Henderson T, Schiltz J, et al. Dengue virus specific IgY provides protection following lethal dengue virus challenge and is neutralizing in the absence of inducing antibody dependent enhancement. PLoS Negl Trop Dis (2017) 11(7):e0005721. doi:10.1371/ journal.pntd.0005721

296. Zhang Y, Yin J, Li T, Zhou B, Xu P, Che R, et al. A recombinant avian antibody against VP2 of infectious bursal disease virus protects chicken from viral infection. Res Vet Sci (2017) 114:194-201. doi:10.1016/j. rvsc. 2017.04 .003

297. Rahman S, Nguyen S, Icatlo F, Umeda K, Kodama Y. Oral passive IgYbased immunotherapeutics: a novel solution for prevention and treatment of alimentary tract diseases. Hum Vaccin Immunother (2013) 9:1039-48. doi: $10.4161 /$ hv. 23383

298. Bhattacharyya T, Sharma A, Akhter J, Pathania R. The small molecule IITR08027 restores the antibacterial activity of fluoroquinolones against multidrug-resistant Acinetobacter baumannii by efflux inhibition. Int J Antimicrob Agents (2017) 50(2):219-26. doi:10.1016/j.ijantimicag.2017.03.005

299. Lu HD, Yang SS, Wilson BK, McManus SA, Chen CVH, Prud'homme RK. Nanoparticle targeting of Gram-positive and Gram-negative bacteria for magnetic-based separations of bacterial pathogens. Appl Nanosci (2017) 7(3-4):83-93. doi:10.1007/s13204-017-0548-0

Conflict of Interest Statement: The authors declare that the research was conducted in the absence of any commercial or financial relationships that could be construed as a potential conflict of interest.

Copyright (C) 2018 Sharma, Rokana, Chandra, Singh, Gulhane, Gill, Ray, Puniya and Panwar. This is an open-access article distributed under the terms of the Creative Commons Attribution License (CC BY). The use, distribution or reproduction in other forums is permitted, provided the original author(s) or licensor are credited and that the original publication in this journal is cited, in accordance with accepted academic practice. No use, distribution or reproduction is permitted which does not comply with these terms. 